\title{
Preserved organic matter in a fossil Ocean Continent Transition in the Alps: the example of Totalp, SE Switzerland
}

\author{
Tsvetomila Mateeva ${ }^{1}\left(\mathbb{D} \cdot\right.$ George A. Wolff $^{1} \cdot$ Gianreto Manatschal $^{2}$ • \\ Suzanne Picazo $^{3} \cdot$ Nick J. Kusznir $^{1} \cdot$ John Wheeler ${ }^{1}$
}

Received: 31 May 2016/Accepted: 13 February 2017/Published online: 2 March 2017

(c) The Author(s) 2017. This article is published with open access at Springerlink.com

\begin{abstract}
Evidence from ultraslow spreading mid-ocean ridges and both fossil and present-day Ocean-Continent Transitions (OCT) demonstrates that mantle serpentinization resulting from the interaction of mantle rock and water during tectonic exhumation is widespread. Observations at white smokers in modern ocean settings suggest that methane produced by serpentinization can support methanotrophic bio-systems, which use methane as the only source of carbon. An important question is whether such bio-systems are more generally pervasive in their association with serpentinized mantle in the subsurface. In this study, we examined whether there is evidence for such a methanotrophic system in exhumed serpentinized mantle at a magma-poor rifted continental margin, by probing for characteristic biological markers in these and associated sedimentary rocks in the Totalp unit of SE Switzerland. This unit represents a remnant of the former OCT of the southern Alpine Tethyan margin and was chosen because of its mild Alpine tectonic and low-grade metamorphic overprint during Alpine orogeny, hence giving potential for the preservation of indigenous organic matter (OM). Totalp samples are characterized by low organic carbon contents of 11-647 ppm. The majority of the samples contain hydrocarbons in the form of $n$-alkanes in the range $\mathrm{C}_{17}-\mathrm{C}_{36}$. Some
\end{abstract}

Editorial handling: C. Sue and S. Schmid.

Tsvetomila Mateeva

mateeva@liv.ac.uk

1 Department of Earth, Ocean and Ecological Sciences, University of Liverpool, Liverpool L69 3BX, UK

2 CNRS-IPGS-EOST, Université de Strasbourg, 1 rue Blessig, 67084 Strasbourg, France

3 University of Lausanne, 1015 Lausanne, Switzerland sediments contain isoprenoids, for example pristane and phytane and a suite of steranes that are consistent with a marine origin for the OM preserved in the rocks. Traces of marine planktonic and bacterial OM are preserved in the serpentinized mantle and overlying sediments of this ancient Tethyan OCT, but there is no evidence that the OM has been generated from methanotrophic bio-systems.

Keywords Serpentinization - Organic matter - Totalp unit · Biogeochemistry · Ocean Continent Transition (OCT)

\section{Introduction}

Serpentinization is an important metamorphic exothermic hydration process potentially contributing chemical energy for anaerobic life, as well as thermal energy at oceanic hydrothermal vents (e.g. Shock et al. 2002; Jamtveit and Hammer 2012). Serpentinization converts olivine and pyroxene to serpentine, other $\mathrm{Fe}-\mathrm{Mg}$ minerals (magnetite, brucite, talc) and free molecular hydrogen (Eq. 1). The Mg component of olivine may hydrate as follows:

$2 \mathrm{Mg}_{2} \mathrm{SiO}_{4}+3 \mathrm{H}_{2} \mathrm{O} \rightarrow \mathrm{Mg}_{3} \mathrm{Si}_{2} \mathrm{O}_{5}(\mathrm{OH})_{4}+\mathrm{Mg}(\mathrm{OH})_{2}$

The Fe component of olivine contributes to forming serpentine by an analogous reaction and/or by reducing water

$6 \mathrm{Fe}_{2} \mathrm{SiO}_{4}+7 \mathrm{H}_{2} \mathrm{O} \rightarrow 3 \mathrm{Fe}_{3} \mathrm{Si}_{2} \mathrm{O}_{5}(\mathrm{OH})_{4}+\mathrm{Fe}_{3} \mathrm{O}_{4}+\mathrm{H}_{2}$

It has been proposed (e.g. McCollom 2013) that molecular hydrogen can then reduce $\mathrm{CO}_{2}$ derived from carbonate and hydrogen carbonate in sea-derived pore waters to methane $\left(\mathrm{CH}_{4}\right)$ at high pressure and temperature, via a FischerTropsch-like reaction (Eq. 3). 
$\mathrm{CO}_{2}+4 \mathrm{H}_{2} \rightarrow \mathrm{CH}_{4}+2 \mathrm{H}_{2} \mathrm{O}$

Serpentinized mantle rocks exposed along slow to ultraslow-spreading Mid-Ocean Ridges (MOR) show positive anomalies of methane and hydrogen in the overlying water column above active tectonic zones (Rona et al. 1987; Charlou et al. 1988; Rona et al. 1992; Bougault et al. 1993; Charlou and Donval 1993; Charlou et al. 1998; Gràcia et al. 2000; Kelley and Shank 2010). The abiotically produced methane can be anaerobically oxidised by methanotrophic bacteria using sulphate as the electron acceptor (Eq. 4).

$\mathrm{CH}_{4}+\mathrm{SO}_{4}^{2-} \rightarrow \mathrm{HCO}_{3}^{-}+\mathrm{HS}^{-}+\mathrm{H}_{2} \mathrm{O}$

Sulphate reducers are one of the dominant bacterial populations at hydrothermal vents (McCollom and Shock 1997). Furthermore, methanotrophic bacteria have been identified at Lost City (mid-Atlantic Ocean), a low-temperature alkaline hydrothermal vent supported by energy derived from the formation of serpentinite (Hinrichs et al. 2000; Kelley et al. 2001; Orphan et al. 2001; Kelley et al. 2005). Recently, bacterial anaerobic nitrate oxidation of methane has been demonstrated in the laboratory (Haroon et al. 2013; Arshad et al. 2015), using two different microorganisms (Raghoebarsing et al. 2006); this may also occur at the MOR methane sources, but is likely to be a minor pathway as nitrate concentrations in seawater are significantly lower than sulphate ( $\mu \mathrm{M}$ vs. $\mathrm{mM}$, respectively).

Recent studies have focussed on the relationship between serpentinization and organic compounds, mainly methane in the laboratory (e.g. McCollom and Seewald 2013; Etiope and Ionescu 2014), at present-day serpentinite-hosted hydrothermal vents (e.g. Kelley et al. 2005; Delacour et al. 2008; Proskurowski et al. 2008), mud volcanoes (e.g. Mottl et al. 2003; Holm et al. 2006), and exhumed serpentinite mantle domains with high $\mathrm{H}_{2}$ concentrations and high $\mathrm{pH}$ (e.g. Cardace et al. 2013). High concentrations of OM found at the Mid-Atlantic Ridge (MAR; 4- $6^{\circ} \mathrm{N}$ ) were associated with serpentinized peridotite rather than with the hydrothermal vents (Ménez et al. 2012).

Hence, the present study uses an organic geochemical approach to quantify $\mathrm{OM}$ in the exhumed mantle from an OCT in order to better understand the relationship between $\mathrm{OM}$ and mantle serpentinization. We selected the Totalp unit exposed in the Eastern Swiss Alps, which represents a remnant of the fossil Tethyan OCT emplaced during the Alpine orogeny (Fig. 1a; Weissert and Bernoulli 1985; Manatschal et al. 2003; Picazo et al. 2013). We searched for biomarkers or molecular remains of former living organisms, specifically hydrocarbons with an origin consistent with anaerobic methane oxidation (e.g. crocetane; Blumenberg et al. 2004). A wider suite of biomarkers was used to determine source and thermal maturity of $\mathrm{OM}$ preserved in the rocks.

\section{Regional geological setting of the Totalp unit}

The Totalp unit is located north of Davos in SE Switzerland. It is part of the Tethyan OCT (Fig. 1b). The peculiarity of the Totalp unit is that it experienced little Alpine deformation and only a low grade Alpine metamorphic overprint, not exceeding $100-150{ }^{\circ} \mathrm{C}$, i.e. prehnitepumpellyite grade (Peters 1968; Früh-Green et al. 1990). The Totalp unit consists of two Alpine tectonic units namely the Upper and Lower Ultramafic Totalp sub-units (e.g. Picazo et al. 2013). These are mainly composed of serpentinized peridotite exhumed at the seafloor during Jurassic times and ophicalcites that occur at the top basement; they can be found re-worked into the overlying Jurassic marine sediments (Fig. 1c). In addition, the primary contacts between the exhumed serpentinized mantle, the ophicalcites and the oceanic sediments are well-preserved (Weissert and Bernoulli 1985).

\subsection{Pre-Alpine and Alpine geological and thermal history}

The serpentinized peridotites of the Totalp unit were exhumed to the Jurassic seafloor during final late Middle Jurassic rifting (Peters and Stettler 1987; Bernoulli et al. 2003). Later, during the Alpine orogeny, the exhumed mantle rocks were first tectonically emplaced within a Late Cretaceous E-W directed nappe stack before being thrusted during the Tertiary collision over the European units forming the present-day Alpine orogen (Weissert and Bernoulli 1985; Früh-Green et al. 1990; Manatschal et al. 2003). The serpentinized peridotites in Totalp are interpreted as derived from fertile subcontinental lithospheric mantle (Manatschal et al. 2001; Müntener et al. 2010; van Acken et al. 2010), similar to other described remnants of fossil OCTs from the Alps (e.g. Platta; Desmurs et al. 2002; Malenco in the Italian Alps; Müntener et al. 2004). Extensional faults and unroofing of their footwalls are responsible for the mantle exposure at the seafloor (Picazo et al. 2013).

\subsection{Lithologies}

The Totalp unit consists mainly of serpentinized peridotites, ophicalcites and post-rift sediments (Figs. 1 and 2; Table 1). This association is typical of an OCT across magma-poor margins where magmatic rocks are often either very rare or absent. Three types of serpentinized mantle rocks were identified: 


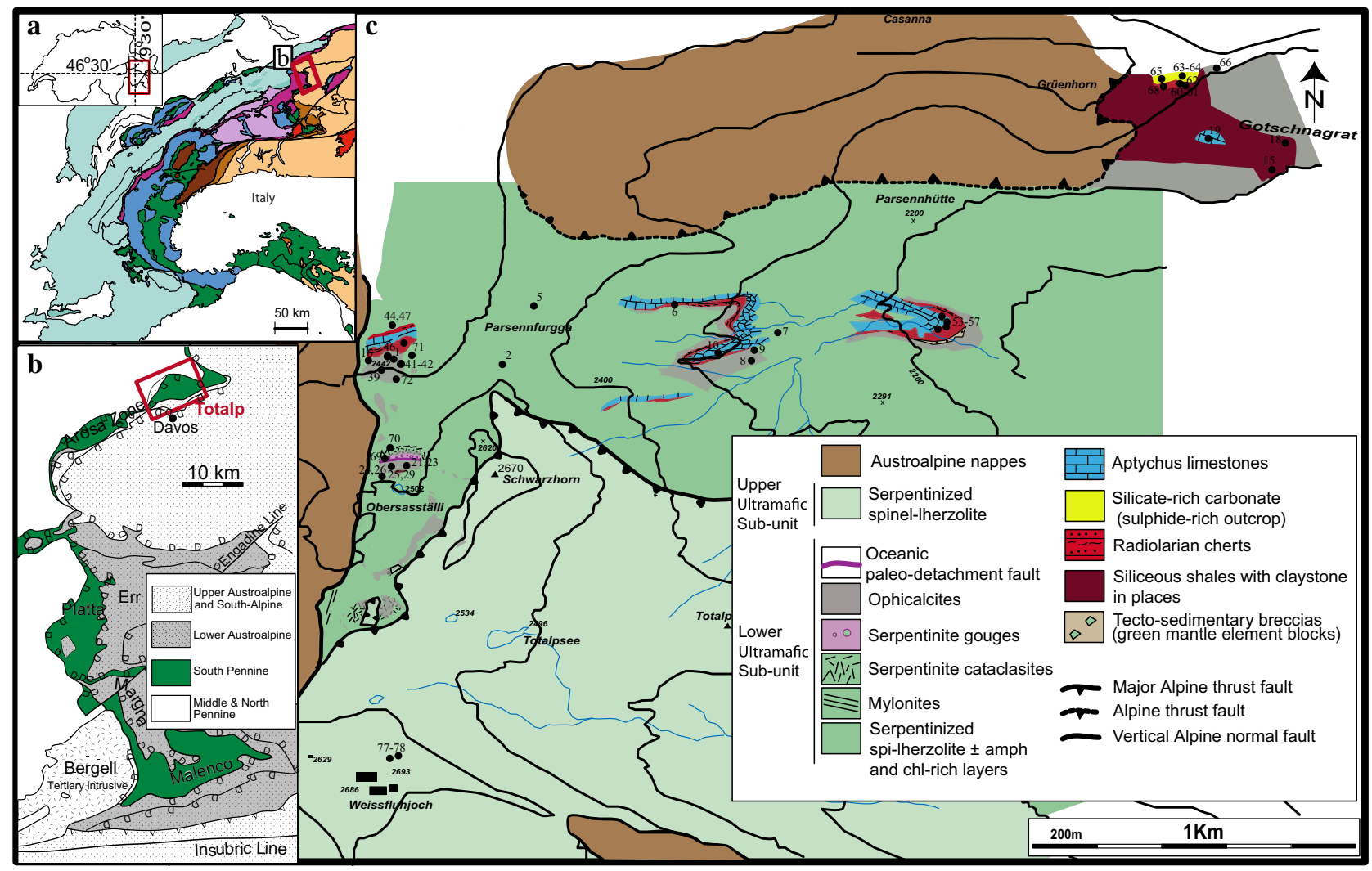

Fig. 1 Maps showing location and geology of the Totalp area. a Location of the Totalp area in the tectonic map of the Alps (from Schmid et al. 2004; modified by Mohn et al. 2010). b Location of Totalp as a part of the South Penninic units in Grisons (Manatschal et al. 2003). c Geological map of Totalp (modified from Picazo et al. 2013) showing location of the analysed samples as well as the distribution of the major lithologies and samples described in this study (for description of samples see Table 1) (i) Massive serpentinized peridotites, which preserve mantle textures and mainly consist of serpentinized spinel-lherzolite. Locally these rocks also contain pyroxenite and amphibole- and chloriterich layers (Picazo et al. 2013).

(ii) During exhumation, the serpentinized peridotites are affected by localization of the deformation and intensive fluid circulation leading to complete serpentinization of fault-rocks, including serpentinite gouges, serpentinite cataclasites and foliated cataclasites (Picazo et al. 2013). These rocks are best exposed in the Obersasställi area, and they occur in the uppermost $150 \mathrm{~m}$ of the exhumed mantle in the footwall of a Jurassic extensional detachment fault (Figs. 1 and 2; Picazo et al. 2013).

(iii) Veins of serpentine that have been interpreted to result from later serpentinization during low-grade Alpine metamorphism, as suggested by the oxygen isotopes (Früh-Green et al. 1990). Some serpentine veins may result from the percolation of meteoric water associated with regional metamorphism (Burkhard and O'Neil 1988).

Ophicalcites are complex rocks that are made of serpentinite and calcite and represent the result of different processes (Bernoulli and Weissert 1985; Lemoine et al. 1987). They either result from the total to partial in situ replacement of serpentine by carbonate, tectonic processes related to exhumation and hydrothermal systems, and/or cementation and filling of fractures by sediments (e.g. neptunian dykes of Bernoulli and Jenkyns 2009). These processes occur at or near the seafloor and are often associated with hydrothermal fluid circulation at temperatures of 100-150 ${ }^{\circ} \mathrm{C}$ (Früh-Green et al. 1990; Picazo et al. 2013). Most ophicalcites are formed under static (non tectonic) conditions within $20 \mathrm{~m}$ of the paleo-seafloor (Picazo et al. 2013).

Sedimentary ophicalcites at Totalp include neptunian dykes and debris-flows (Fig. 2). The neptunian dykes are carbonate veins filled with pink or grey carbonate (pelagic sediments or mechanically reworked cements), filling fractures in the exhumed mantle. These dykes are typically located in the tectonized, serpentinized peridotites forming 


\section{Log of Totalp exhumed mantle and sedimentary cover}

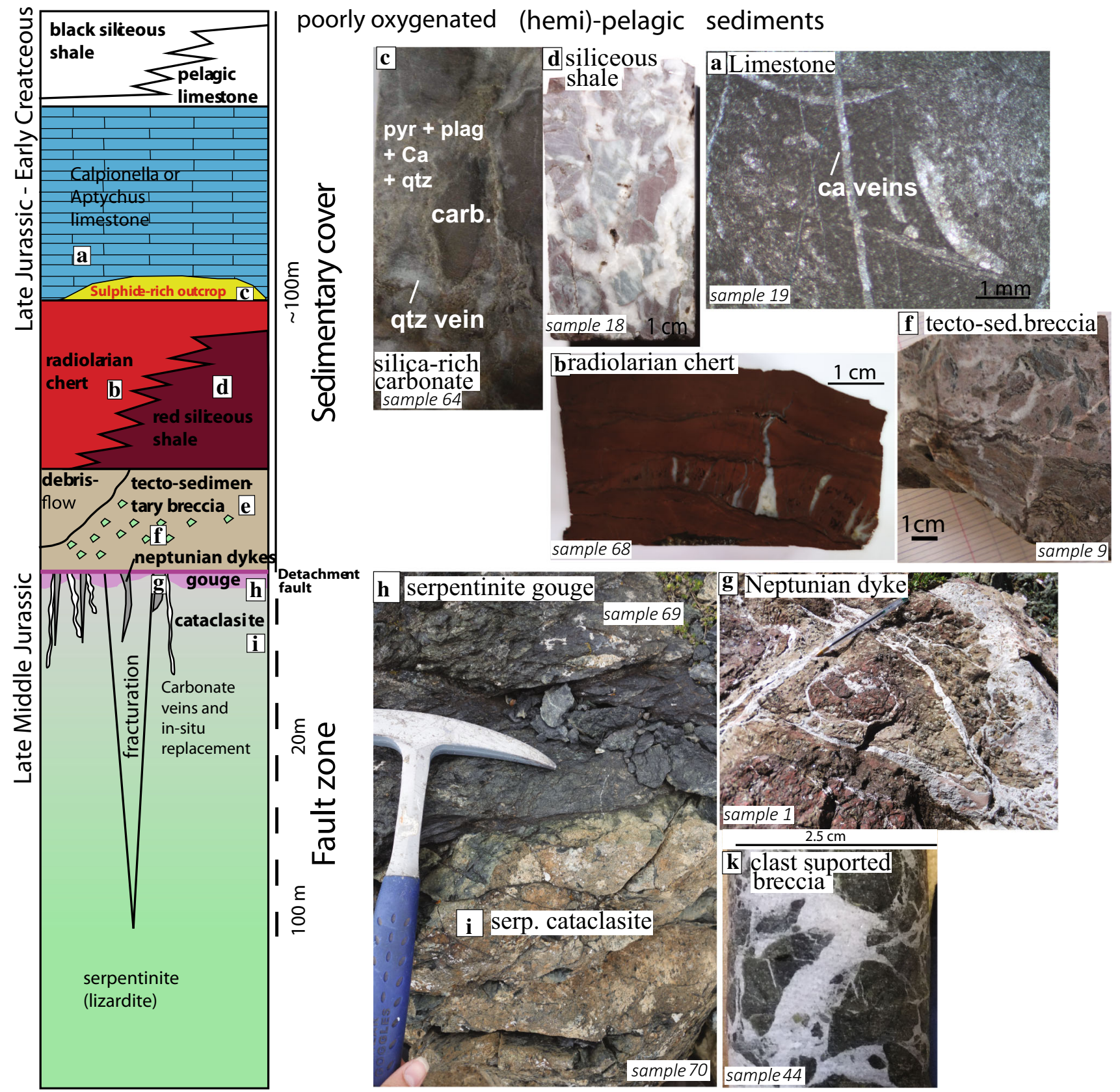

Fig. 2 Sketch showing the lithologies and the stratigraphy of the Totalp area (Weissert and Bernoulli 1985; Früh-Green et al. 1990; Manatschal et al. 2003; Picazo et al. 2013)

the uppermost few meters of the exhumed mantle (Bernoulli and Weissert 1985; Picazo et al. 2013). The second main type, the tectono-sedimentary ophicalcites, include cemented clasts of serpentinite, gabbro and continental basement (Manatschal and Bernoulli 1999; Bernoulli et al. 2003; Picazo et al. 2013).

The sediments overlying the ophicalcite are mainly pelagic deposits of Late Jurassic to Early Cretaceous age, some of which have been reworked (most likely by ocean bottom currents) (Weissert and Bernoulli 1985). Red shales are overlain by radiolarian cherts and grey micritic limestones intercalated with claystones (e.g. Radiolarite Formation and Calpionella or Aptychus limestone Formation of Weissert and Bernoulli 1985). The top of the sequence is formed by black siliceous shales that are characteristic of poorly oxygenated bottom waters during the Early Cretaceous (Weissert et al. 1985; Weissert and Bernoulli 1985). 


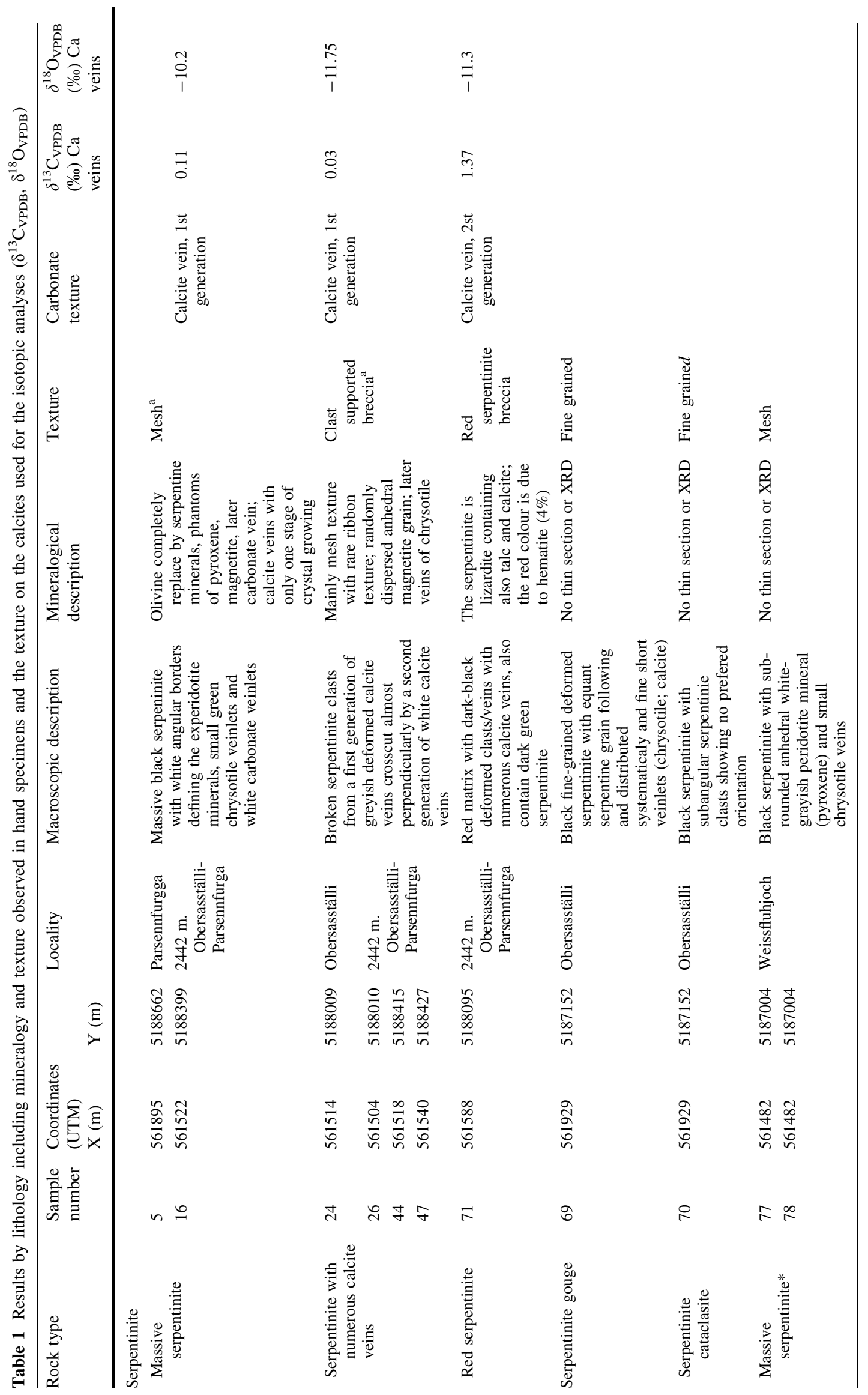




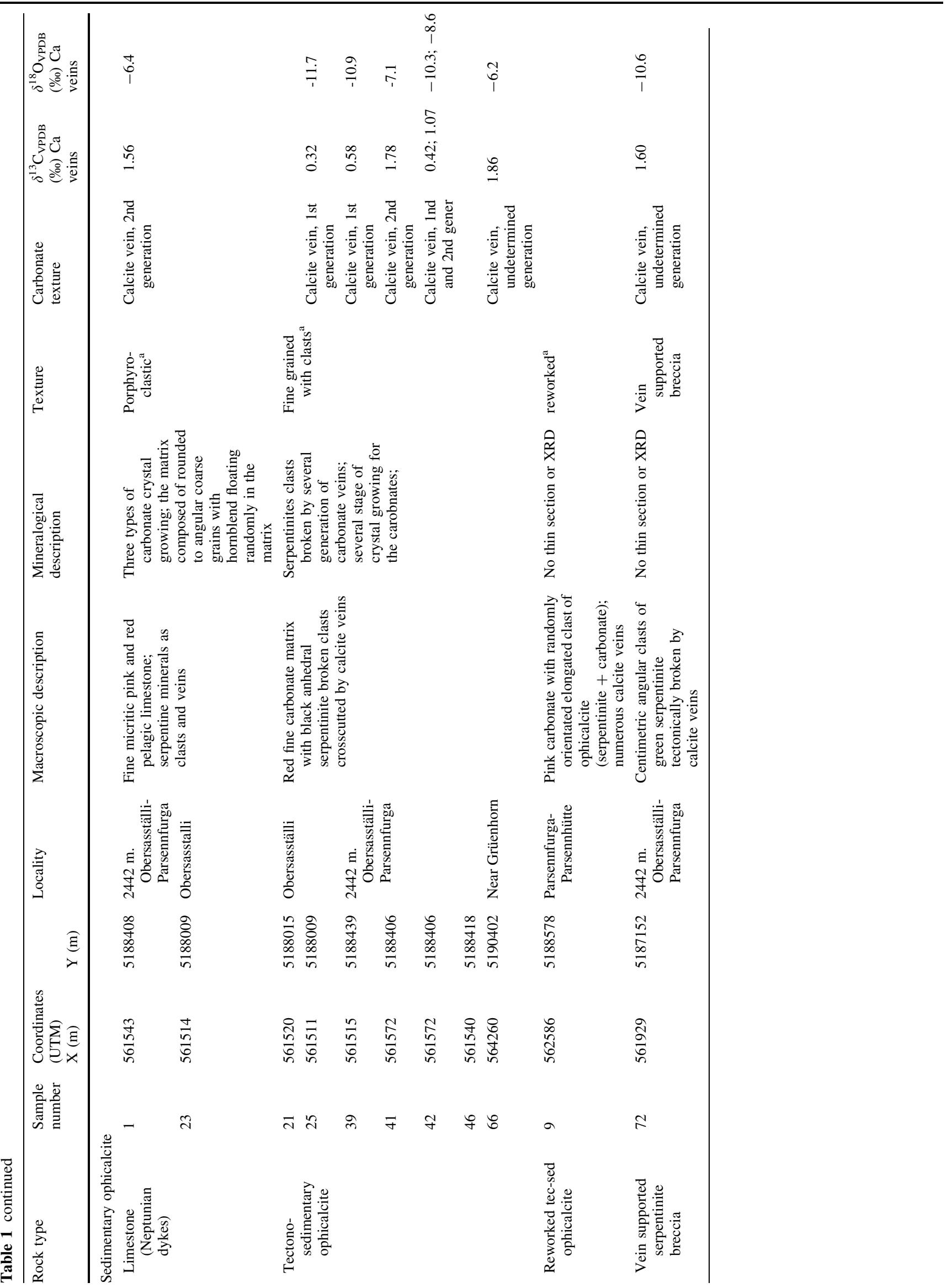




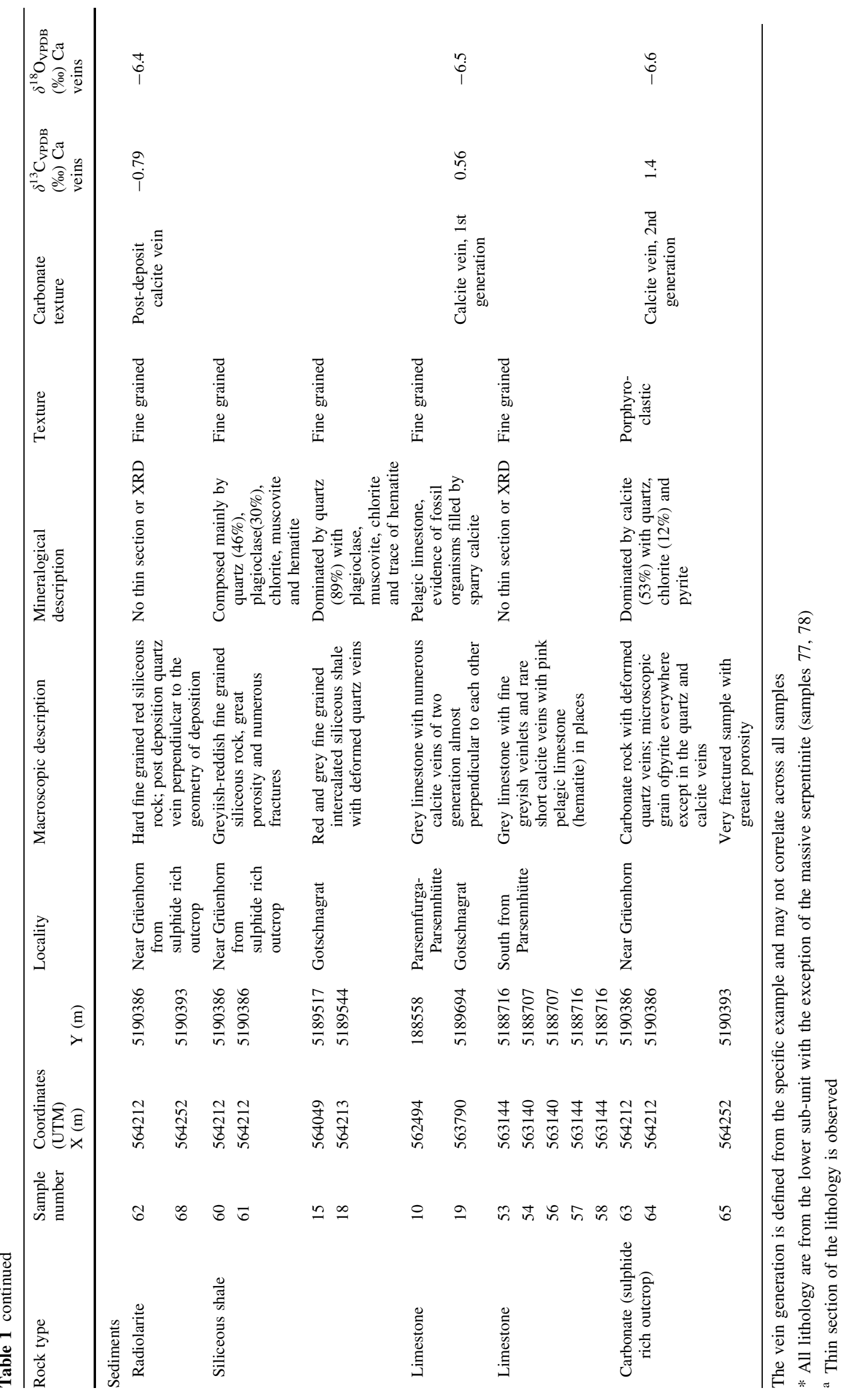



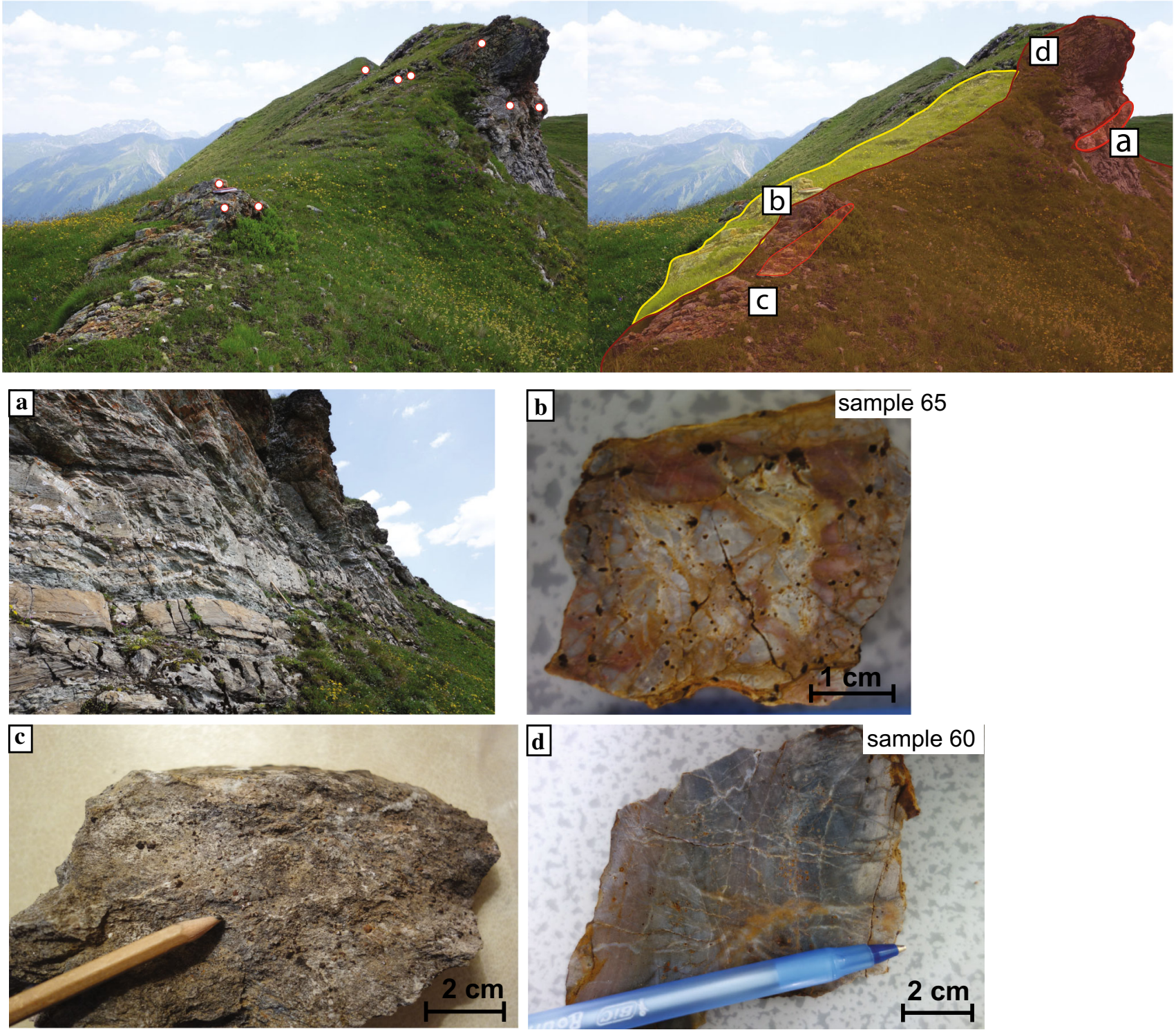

Fig. 3 The sulphide bearing outcrop in the Totalp area showing weathered lithology. Red circles are the sampling location in this outcrop. In the line-drawing on the right, light red identifies radiolarian cherts, dark red siliceous shale and yellow sulphate rich carbonate, rich in silica. a Zoom of outcrop. b Sample 65 is composed

North east of Totalp, exposed on a topographic cliff near Gotschnagrat (Figs. 1 and 2), is a weathered outcrop with visible pyrite on the top of the radiolarian cherts and siliceous claystones (Fig. 3; Weissert and Bernoulli 1985). This outcrop has been described by Früh-Green et al. (1990) as a zone of pyrite mineralization associated with radiolarian cherts. The radiolarites contain quartz, illite, hematite and chlorite (Weissert and Bernoulli 1985). The sulphidized outcrop has a bulk chemistry different from its surrounding and could have been formed during early diagenesis or metasomatism of amorphous silica or limestone (Berner 1984; Williams et al. 1985). Alternatively,

by calcite $50 \% .25 \%$ quartz and is highly weathered. c Sample shows visible hematite crystals and calcite as the major mineral. d Sample 60 shows a siliceous rock with 3 different colours composed by $83 \%$ quartz, $10 \%$ albite and pyrite, illite and chlorite

the sulphide could be related to a fossil hydrothermal system (e.g. Styrt et al. 1981, Beard and Hopkinson 2000; Zeng et al. 2015). Early diagenetic reactions producing pyrite depend inter alia on a source of $\mathrm{OM}$ as electron donor (Fig. 3b); the high present-day porosity of the rock (Fig. 3c) could be produced by weathering of calcite (Berner 1984). Hydrothermal vent systems are characterized by pelagic sediment accumulation alongside ferrous oxides (i.e. radiolarian chert) of hydrothermal origin which can potentially be preserved (Haymon 1989; Montgomery and Kerr 2009). The second most common mineral in the sulphide bearing samples is quartz that may have 
originated from amorphous silica or opal, which are common in hydrothermal vents (e.g. MAR- mount Saldanha $36^{\circ} 30^{\prime} \mathrm{N}$; Dias and Barriga 2006, $25^{\circ} 48^{\prime} \mathrm{N}$ Rona 1984 , $24^{\circ} 21^{\prime} \mathrm{N}$; Rona 1984; Kane $23^{\circ} 35^{\prime} \mathrm{N}$ Fracture zone; Kelley and Delaney 1987) reflecting a large input of hydrothermal silica (Dias and Barriga 2006). There is no evidence of fossilized worm tubes associated with the zone of pyrite mineralization; these are characteristic of inactive white smokers (Haymon 1983) and so the origin of this formation remains unclear.

\section{Sample collection, preparation and analysis}

\subsection{Sample collection}

A total of 47 samples were selected from the Totalp unit for geological and organic geochemical studies (Table 1). We collected samples from the three main lithologies: serpentinized mantle rock (lizardite, serpentinite gouge and cataclasite), ophicalcites (neptunian dykes and tectonosedimentary breccias) and associated sediments (Figs. 1 and 2; Table 1). Samples were oriented, geo-referenced and collected using a geological hammer or a hand drill using water as lubricant. On collection the samples were wrapped in pre-combusted foil $\left(400{ }^{\circ} \mathrm{C}\right)$ for return to the laboratory.

\subsection{Sample preparation}

In order to avoid contamination with modern material the samples were cleaned with de-ionised water $\left(18 \mathrm{M} \Omega \mathrm{cm}^{-1}\right.$ resistivity; Milli-Q) and rinsed with re-distilled dichloromethane (DCM). The outer edges were removed from each sample, which was then cut into smaller pieces using a small rock saw lubricated with water. The aim was to get fresh, unweathered samples for laboratory analysis. These were then used for preparing thin sections and for stable isotope analyses of carbonate veins, with $90-110 \mu \mathrm{g}$ of calcite being extracted using a small electrical hand drill. For organic geochemistry selected pieces were washed with Milli-Q water and DCM, then crushed (to particles $<50 \mu \mathrm{m}$ ) using a tungsten Tema Mill, which was previously thoroughly cleaned (Decon-90 solution 2\% v/v, milli-Q water, methanol and finally DCM). In order to assess lab contamination, blanks composed of pre-combusted silica gel $\left(600{ }^{\circ} \mathrm{C}\right)$ were subjected to the same procedures as the samples.

\subsection{Mineralogical analyses}

Optical microscopy, cathodoluminescence microscopy (CL; CITL Mk5-2) and X-ray diffraction (XRD) were used to identify the mineralogy, chemistry, texture and textural relations within the samples and to associate the mineralogy with the OM. A Panalytical X'Pert PRO XRD system ( $\mathrm{CuK}^{-\alpha}$ radiation, $45 \mathrm{kV}, 40 \mathrm{~mA}$ ) was used to identify the volume proportions of the minerals associated with serpentinization and the polytypes of the serpentine minerals.

\subsection{Geochemical analyses}

Analyses of total carbon (TC) and total organic carbon (TOC) were performed before and after decarbonation $\left(10 \% \mathrm{HCL}, 25^{\circ} \mathrm{C}\right)$, respectively, using a Carlo Erba Instrument NC2500 elemental analyser.

Stable isotopic analyses of organic carbon were carried out on five samples of four different lithologies, prepared using a "sealed tube" method and injecting the resulting $\mathrm{CO}_{2}$ into a VG Sira 10 dual-inlet mass spectrometer (Craig 1957; Frazer and Crawford 1963; Sofer 1980). The standard error for analysis is $\pm 0.1 \%$. The isotope data was normalized to IAEA-CH7 calibration material and reported using the VPDB scale. Carbon and oxygen isotope measurements on calcite were performed on material extracted from veins by conversion to $\mathrm{CO}_{2}$ using a VG SIRA 10 MS Isocarb (common acid bath). The carbon and the oxygen isotope analyses are referenced to the VPDB standard with a standard error for each analysis of $\pm 0.1 \%$ (McCrea 1950; Craig 1957; Friedman and O’Neil 1977; Swart et al. 1991).

Soxhlet extraction was used to extract the bitumen from the powdered rocks using DCM: methanol (ratio 9:1) (24 h) (modified after Wolff et al. 1995). Full blank extractions were conducted in parallel to identify any possible contamination. After evaporation of the solvent, the extracts were re-dissolved and passed through short columns of alumina and sodium sulphate using hexane as solvent to isolate the hydrocarbons. The eluent from the alumina column was re-dissolved in hexane $(50 \mu \mathrm{L})$ and analysed by gas chromatography (GC) and GC-mass spectrometry (GC-MS).

For GC-MS we used a GC Trace 1300 and Thermoquest ISQMS single quadrupole fitted with a split-splitless injector, GC column (DB-5MS non-polar 5\% phenyl and $95 \%$ methyl silicone stationary phase, $60 \mathrm{~mm} \times 0.25 \mathrm{~mm}$ i.d., film thickness $0.1 \mu \mathrm{m}$ ) using helium as a carrier gas $\left(2 \mathrm{~mL} \min ^{-1}\right)$. The $\mathrm{GC}$ oven temperature was programmed from 60 to $170{ }^{\circ} \mathrm{C}$ after $1 \mathrm{~min}$ at $6{ }^{\circ} \mathrm{C} \mathrm{min}{ }^{-1}$, then from 170 to $315^{\circ} \mathrm{C}$ at $2.5^{\circ} \mathrm{C} \mathrm{min}{ }^{-1}$ and finally held at $315^{\circ} \mathrm{C}$ for $15 \mathrm{~min}$. GC-MS was carried out in full data acquisition mode, providing mass spectra of compounds eluting from 20 to $90 \mathrm{~min}$; these were identified by comparison with the literature and with authentic standards where available (PAHs-polynuclear aromatic hydrocarbons). 5 $\alpha(\mathrm{H})$-Cholestane was used as an external standard for quantification; response factors were assumed to be 1 , hence data are 


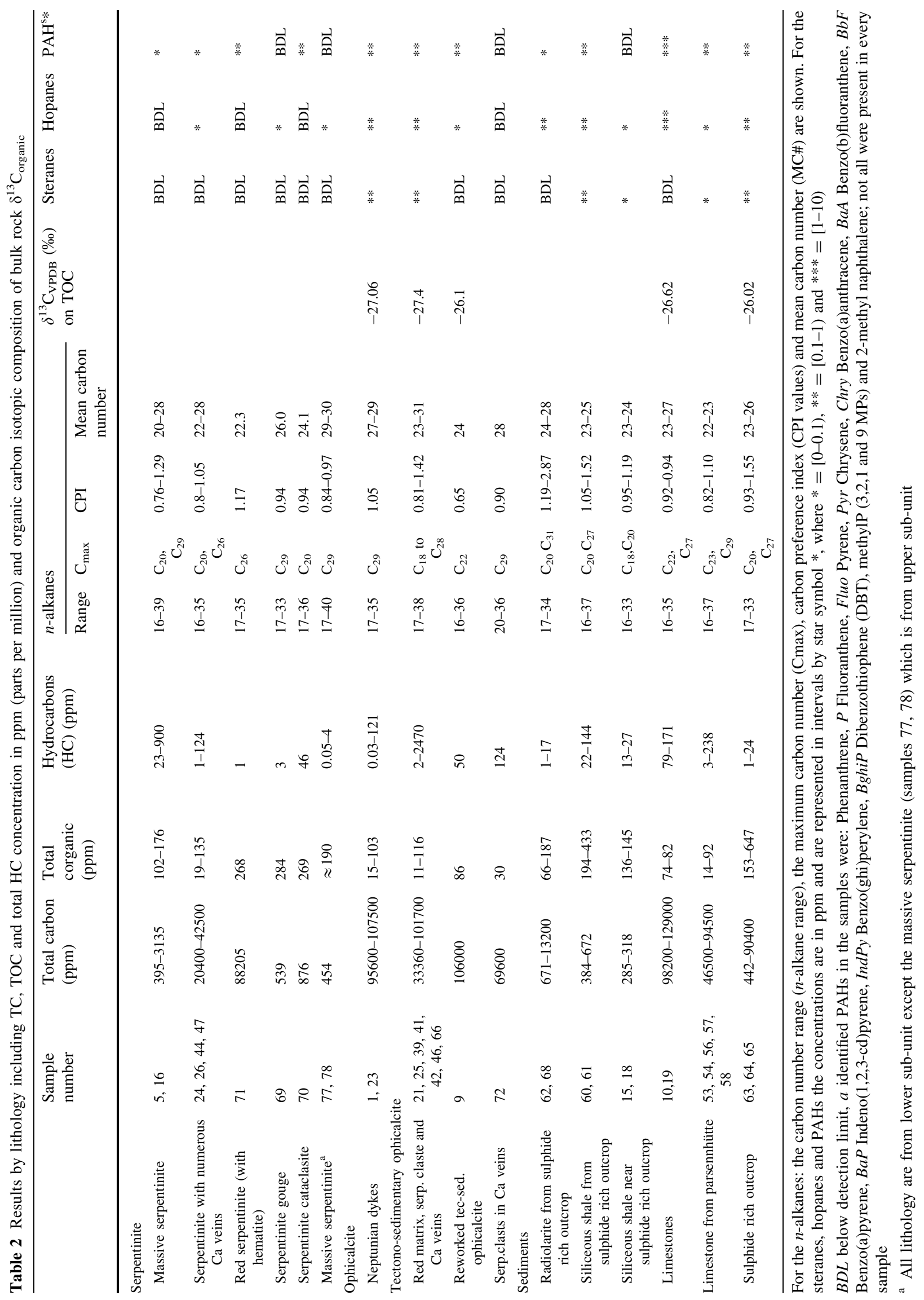


semi-quantitative. Data were processed using XCalibur 1.2 software (ThermoScientific).

The mean carbon numbers, MC\# (Peltzer and Gagosian 1989) and the carbon preference index (CPI) of $n$-alkanes (Peters et al. 2005a) were calculated over the carbon number range $\mathrm{C}_{20}-\mathrm{C}_{37}$ (Eqs. 5 and 6; Table 2).

$\mathrm{MC} \#=\sum\left(\left[C_{i}\right] x C_{i}\right) / \sum\left[C_{i}\right]$

where $\left[C_{i}\right]=$ concentration of the $n$-alkane with $C_{i}$ carbon number

$$
\begin{aligned}
& \mathrm{CPI}=0.5 x \sum\left(\left[\text { odd } C_{21}-C_{35}\right]\right) / \\
& \quad\left(\left[\text { even } C_{20}-C_{34}\right]+\sum\left[\text { odd } C_{23}-C_{37}\right] / \sum\left[\text { even } C_{22}-C_{36}\right]\right)
\end{aligned}
$$

\section{Carbon and hydrocarbon distributions in the analysed lithologies}

The TOC and TC results are summarized in Table 2 and vary considerably. The TOC values are low, while TC reflect carbonate contents. The stable isotopic composition of carbonate varied from -0.78 to $1.86 \%$ VPDB and -11.7 to $-6.2 \%$ VPDB for $\delta^{13} \mathrm{C}$ and $\delta^{18} \mathrm{O}$, respectively (Table 2; Fig. 4). Five decarbonated samples (sample 1: neptunian dyke; samples 9 and 39: reworked tectono-sedimentary ophicalcite; sample 19: limestone; sample 69: specimen from the sulphide-rich outcrop) have similar values for $\delta^{13} \mathrm{C}_{\text {VPDB organic }}$ of between -27.4 and $-26.2 \%$ (Table 2).

Hydrocarbons (HCs) identified in Totalp samples include $n$-alkanes, steranes, polynuclear aromatic hydrocarbons (PAHs), hopanes and isoprenoids, namely pristane and phytane. Samples of the same lithology do not necessarily have similar distributions of HCs (Table 2). This may reflect the heterogeneity of the samples collected, for

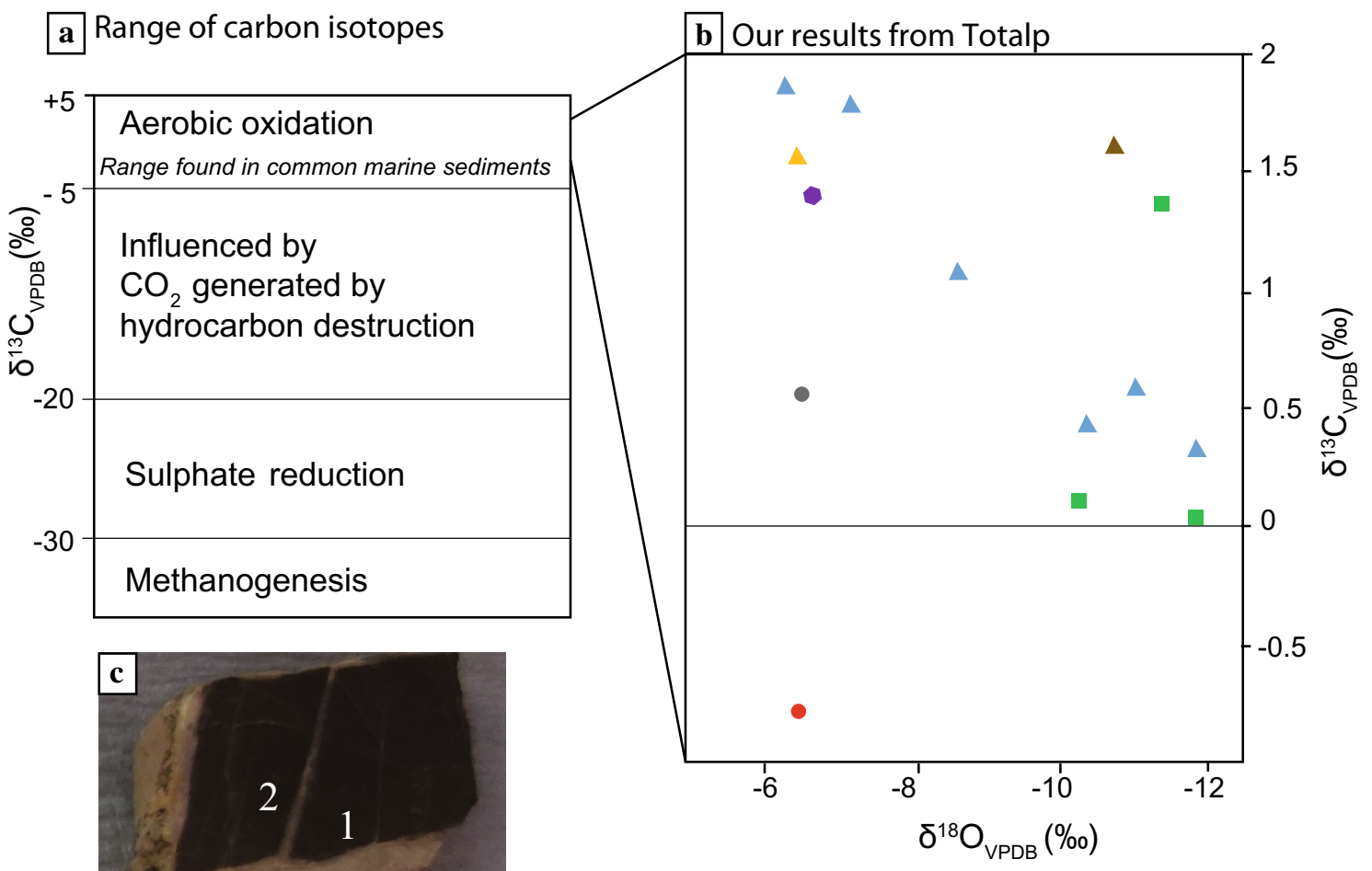

Measurements in calcite veins in:

Serpentinite (lower sub-unit)

Limestone

Radiolarian chert Sulphide rich outcrop
Ophicalcite:

neptunian dykes tectono-sedim.breccias serp. clast in $\mathrm{Ca}$ veins

oxygen isotopic composition of calcite veins in Totalp samples. c Limestone (sample 19) showing two generations of calcite veins

Fig. 4 a Global range of carbon isotopic composition of carbonates precipitated during early diagenetic processes (modified after Coleman et al. 1993; Kiriakoulakis 1997; Heydari 1997). b Carbon and 

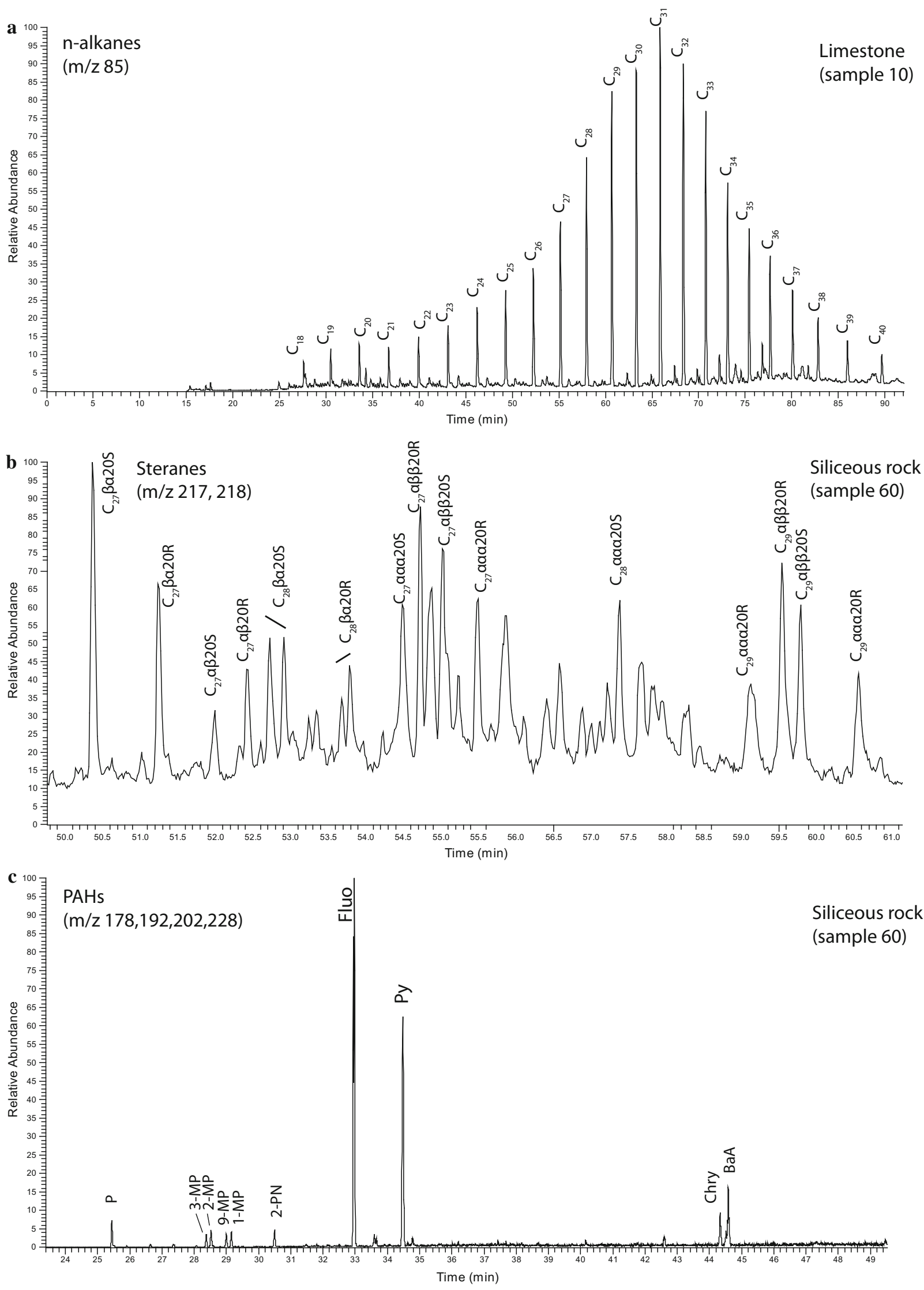
4Fig. 5 Representative mass chromatograms of the HCs of a typical sample of limestone (sample 10) and a siliceous rock from the sulphide rich outcrop of Totalp (sample 60). a $n$-alkanes (m/z 85) of sample 10 (limestone) b sterane distribution $(\mathrm{m} / \mathrm{z} 217,218)$ of sample 60 c PAH distribution $(\mathrm{m} / \mathrm{z} 178,192,202,228)$ of sample 60 . For abbreviations see appendix

example in the relative amount of carbonate, calcite veins and serpentinite clasts.

Aliphatic compounds (>C15), mainly in the form of $n$ alkanes dominate (Fig. 5a). The CPI (carbon preference index) for the $n$-alkanes are in the range $1 \pm 0.3$, except for two samples that were visibly weathered, having CPI $=2.6-2.87$, i.e. an odd over even ratio for the $n$ alkanes confirming contamination from modern material, such as soil (e.g. Villanueva et al. 1997). Steranes included $20 \mathrm{R}$ and $20 \mathrm{~S} \alpha \beta \beta$ isomers from $\mathrm{C}_{27}$ to $\mathrm{C}_{29}$, as well as $20 \mathrm{R}$ and $\mathrm{S}$ diacholestane and pseudohomologues (Fig. 5b). The steranes were dominated by $\mathrm{C}_{27}$ compounds with a lower abundance of $\mathrm{C}_{28}$ and $\mathrm{C}_{29}$ pseudo-homologues (Fig. 5b). The ranges of values for the thermal maturity parameters of the $\mathrm{C}_{27}$ steranes are between 0.41 and 0.69 for ST1 $=\alpha \alpha \alpha$ $20 \mathrm{~S} / \alpha \alpha \alpha 20 \mathrm{~S}+\alpha \alpha \alpha \quad 20 \mathrm{R}$ and 0.37 and 0.59 for $\mathrm{ST} 2=\alpha \beta \beta / \alpha \alpha \alpha+\alpha \beta \beta$ (Fig. 6; Seifert and Moldowan 1980; Peters et al. 2005b). PAHs having molecular masses $\leq 276$ were identified in some of the bitumen extracts (Table 2; Fig. 5c).

\subsection{Serpentinite}

All serpentinite samples contain $n$-alkanes, and several PAHs in the form of phenanthrene $(\mathrm{P})$ and fluoranthene (Fluo); steranes and hopanes were largely absent (Table 2).

\subsubsection{Upper ultramafic sub-unit}

4.1.1.1 Massive serpentinite The massive serpentinites collected from the Weissfluhjoch (samples 77, 78; Fig. 1c; Table 1) area have HC concentrations between 0.05 and 4 ppm while the $\mathrm{C}_{29} n$-alkane dominates their distribution $\left(\mathrm{C}_{\max }=29\right.$; Table 2). Total carbon $(454 \mathrm{ppm})$ and total organic carbon $(\mathrm{TOC})(\approx 180 \mathrm{ppm})$ concentrations are both very low.

\subsubsection{Lower ultramafic sub-unit}

4.1.2.1 Massive serpentinite XRD analysis shows a lizardite polytype 1 (Bailey 1969) (87\%), garnet (andradite) $(7 \%)$ and pyroxene (clinopyroxene) $(5 \%)$. In thin section olivine is completely replaced by serpentine minerals, with phantoms of pyroxene, euhedral magnetite, spinel and several calcite and carbonate veins not visible to the naked eye (Table 1).

$\mathrm{HC}$ concentrations vary from $23 \mathrm{ppm}$ for the serpentinite from Parsenfurgga (sample 5) to $900 \mathrm{ppm}$ from an outcrop with ophicalcite in Obersasställi (sample 16; Fig. 1c; Table 2). The TOC values range from 102 to $176 \mathrm{ppm}$ and TC from 395 to $3134 \mathrm{ppm}$; steranes and hopanes are below detection limits (BDL) (Table 2). Serpentinite samples showing numerous calcite veins (sample 24, 26, 44 and 47) have higher amounts of TC (20400-42500 ppm). They show variable TOC (19-135 ppm) and low HC concentrations (1-124 ppm). In the lower ultramafic sub-unit a red coloured serpentinite was identified by XRD to contain hematite (4\%) (Table 1). The serpentine mineral is a lizardite polytype $1(59 \%)$, also containing talc $(18 \%)$ and calcite $(19 \%)$. The isotopic composition of the calcite in the veins is 0.03 and
Fig. 6 Thermal maturity parameters of $\mathrm{C}_{27}$ steranes for Totalp samples. The classification is from Peters et al. 2005a. The brown shaded area represents the range of complete isomerization for the $20 \mathrm{~S} /(20 \mathrm{~S}+20 \mathrm{R}) \alpha \alpha \alpha \mathrm{C}_{27}$ steranes (ca. 55\%) and $\alpha \beta \beta /$ $(\alpha \alpha \alpha+\alpha \beta \beta) \mathrm{C}_{27}$ steranes (ca. $68 \%)$

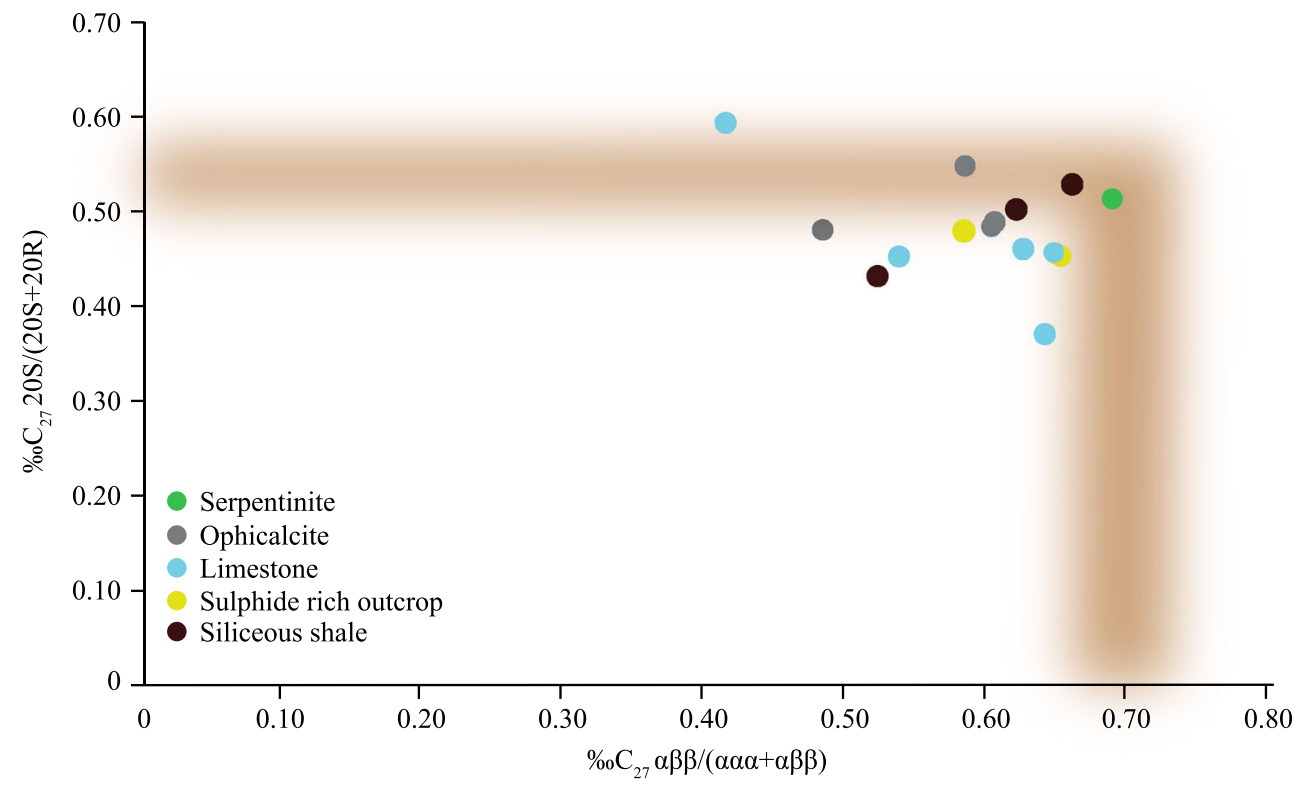


$-11.75 \%$ for $\delta^{13} \mathrm{C}_{\mathrm{VPDB}}$ and $\delta^{18} \mathrm{O}_{\mathrm{VPDB}}$, respectively (Fig. 4).

\subsubsection{Serpentinite cataclasite and gouges}

The serpentine cataclasites and gouges have TC of 540-875 ppm, $n$-alkanes with a carbon number range of $\mathrm{C}_{17}-\mathrm{C}_{36}$ and no detectable steranes or hopanes (Tables 1 and 2). The serpentine cataclasites (sample 70), which are less deformed than the serpentine gouge (sample 69), contain more hydrocarbons (46 and $3 \mathrm{ppm}$, respectively Table 2) but similar TOC contents (284 and $269 \mathrm{ppm}$, respectively).

\subsection{Ophicalcite}

The ophicalcites from the Totalp unit all contain $n$-alkanes and the PAHs (P, Fluo and Pyr, see glossary; Table 2). Steranes and hopanes are also present in the majority of samples.

\subsubsection{Neptunian dykes}

Samples of neptunian dykes have a red micritic limestone matrix with millimetre-scale serpentinite clasts and calcite veins (samples 1, 23) (Fig. 1c; Table 1). The $\delta^{13-}$ $\mathrm{C}_{\mathrm{VPDB}}$ organic of one of the samples (sample 1) was $-27.1 \%$ (Table 2). There are high amounts of TC with variable TOC (15-103 ppm) and HC concentrations (0.3-121 ppm) (Table 2).

\subsubsection{Tectono-sedimentary ophicalcites}

The tectono-sedimentary ophicalcite has various sublithologies from a reworked tectono-sedimentary breccia with folded serpentinized and carbonate clasts in a red carbonate matrix crosscut by calcite veins (sample 9) to centimetre scale serpentinite clasts in a carbonate vein (sample 72) (Fig. 1c; Table 1). The stable isotopic composition $\delta^{13} \mathrm{C}_{\mathrm{VPDB}}$ organic of one of the samples was $-26.1 \%$ (sample 9) (Table 2). A second type of ophicalcite, a serpentinite breccia composed only of serpentinite clasts fragmented by calcite veins has low TOC (30 ppm) and HCs concentrations (124 ppm) including only $n$-alkanes (sample 72) (Table 2). The isotopic compositions of the calcite veins surrounding the serpentinite clast are $1.60 \%$ and $-10.6 \%$ VPDB for $\delta^{13} \mathrm{C}$ and $\delta^{18} \mathrm{O}$, respectively. The third most common ophicalcite is composed of anhedral serpentinite clasts, carbonate veins, calcite veinlets in a reddish pelagic matrix and has a low amount of TOC (11-116 ppm), but high concentrations of HCs (2-2470 ppm) (samples 21, 25, 39, 41, 42, 44, 66; Fig. 1c; Tables 1 and 2). The isotopic composition of the samples varies from $\delta^{13} \mathrm{C}_{\mathrm{VPDB}}=0.32 \%$, $0.42 \%$ and $0.58 \%$ with $\delta^{18} \mathrm{O}_{\mathrm{VPDB}}=-11.75 \%,-10.28 \%$ and $-10.9 \%$ (for samples 25,42 and 39 respectively) to $\delta^{13} \mathrm{C}_{\mathrm{VPDB}}=1.07$ and $1.78 \%$ with $\delta^{18} \mathrm{O}_{\mathrm{VPDB}}=-11.7$ to $-7 \%$ o for samples 42 (second generation calcite vein) and 41 (Fig. 4; Table 1). Isotopic analysis of organic carbon (sample 39) gave $\delta^{13-}$ $\mathrm{C}_{\mathrm{VPDB}}$ organic $=-27.4 \%$ (Table 2$)$. The ophicalcite outcrop near the Gotschnagrat NE Totalp has isotopic values for calcite veins of $1.86 \%$ for $\delta^{13} \mathrm{C}_{\mathrm{VPDB}}$ and $-6.2 \%$ for $\delta^{18} \mathrm{O}_{\mathrm{VPDB}}$ (sample 66).

\subsection{Sediments}

Limestones are, together with radiolarian cherts, the most common sediments in the Totalp unit. All of the sediment samples contain detectable levels of HCs including PAHs.

\subsubsection{Radiolarian cherts}

The radiolarian cherts are situated mostly around the Gotschnagrat NE Totalp (samples 62, 68) and along small distributed outcrops some of which are 1-2 $\mathrm{m}$ in length and located between Parsennfurgga and Parsenhütte (sample 6; Fig. 1c). Except for the weathered sample, they have very low concentrations of HCs (1-17 ppm) and low TOC values (66-187 ppm) (Table 2). The radiolarian cherts are hard, fine grained siliceous sediments that are transected by post-depositional quartz and calcite veins, the latter having isotopic compositions of $\delta^{13} \mathrm{C}_{\mathrm{VPDB}}=-0.79 \%$ and $\delta^{18-}$ $\mathrm{O}_{\mathrm{VPDB}}=-6.4 \%$ (Sample 62; Table 1; Fig. 4).

\subsubsection{Siliceous shales}

The siliceous shales are located mostly above Parsennhütte and around the Gotschnagrat (samples 15, 18, 60, 61; Fig. 1c). XRD analysis of the siliceous shales (sample 61) above the pyrite rich area revealed a mineralogical composition consisting of quartz (83\%), albite $(10 \%)$, pyrite (2\%), illite/muscovite (4\%), chlorite and hematite. This composition is similar to the siliceous shale (samples 15 , 18 ) found nearby, which consists of quartz (89\%), plagioclases (6\%), illite/muscovite (4\%), chlorite and trace of hematite (Fig. 1c; Table 1). They have low concentrations of HCs (13-144 ppm) and variable amounts of TOC (194-433 ppm) (Table 2).

\subsubsection{Limestone}

Samples (53-57) are pelagic grey limestones that contain visible calcite veinlets and fine greyish veinlets (serpentinite) from the syncline in the Parsennhütte (Fig. 1c; Table 1). They contain a low amount of TOC (14-92 ppm) and variable concentrations of HCs (Table 2). 
The pelagic limestones with higher amount of calcite veins (samples 10, 19) are also poor in TOC (74-82 ppm) and contain HCs from 79 to $171 \mathrm{ppm}$ (Fig. 1c; Tables 1 and 2). Isotopic analyses of the first generation of calcite veins in sample 19 show $\delta^{13} \mathrm{C}_{\mathrm{VPDB}}=0.56 \%$ and $\delta^{18-}$ $\mathrm{O}_{\mathrm{VPDB}}=-6.5 \%$ and $\delta^{13} \mathrm{C}_{\mathrm{VPDB}}$ organic $=-26.6 \%$ (Fig. 4 ; Table 1).

\subsection{Silica-rich carbonate (sulphide-rich outcrop)}

The mineralogy of the pyrite rich rocks is dominated by calcite $(53 \%)$ with quartz $(24 \%)$, chlorite $(12 \%)$ and pyrite (6\%) being the other main minerals (sample 63, 64, 65; Figs. 1c and 3; Table 1). The samples were on the top of the radiolarian chert and red shale sequences where the contact between these rocks are weathered and not affected by deformation (Fig. 3). Isotopic composition of organic carbon is $\delta^{13} \mathrm{C}_{\mathrm{VPDB}}$ organic $=-26.02 \%$ (sample 64 ) and that of the calcite veins in the same sample $1.4 \%$ for $\delta^{13} \mathrm{C}_{\mathrm{VPDB}}$ and $6.6 \%$ for $\delta^{18} \mathrm{O}_{\mathrm{VPDB}}$ (Table 1). The samples are characterized by a TOC contents from 153 to $647 \mathrm{ppm}$ and low HC concentrations (1-24 ppm) (Table 2); bitumen extracts are dominated by elemental sulphur, but HCs include $n$-alkanes, PAHs (P, Fluo, MPs) and steranes (Table 2).

\section{Interpretation and discussion}

Traces of OM with a composition consistent with a marine origin were found in the serpentinized exhumed mantle. The generally low and variable amounts of TOC reflects the large lithological diversity of the Totalp area, and the distributions of hydrocarbons are consistent with the temperature history of the Totalp unit (i.e. no metamorphic overprint) (Table 2; Fig. 5).

\subsection{Source of OM}

A cross-plot of Pristane (Pr) to $n-\mathrm{C}_{17}$ versus phytane $(\mathrm{Ph})$ to $n-\mathrm{C}_{18}$ is commonly used to determine the depositional environment of $\mathrm{OM}$ in sedimentary rocks (Peters et al. 2005b). For the Totalp samples (Fig. 7), this cross-plot implies a reducing (anoxic) depositional environment for the OM, with a marine source of planktonic algal/bacterial $\mathrm{OM}$ consistent with a marine mixed transitional

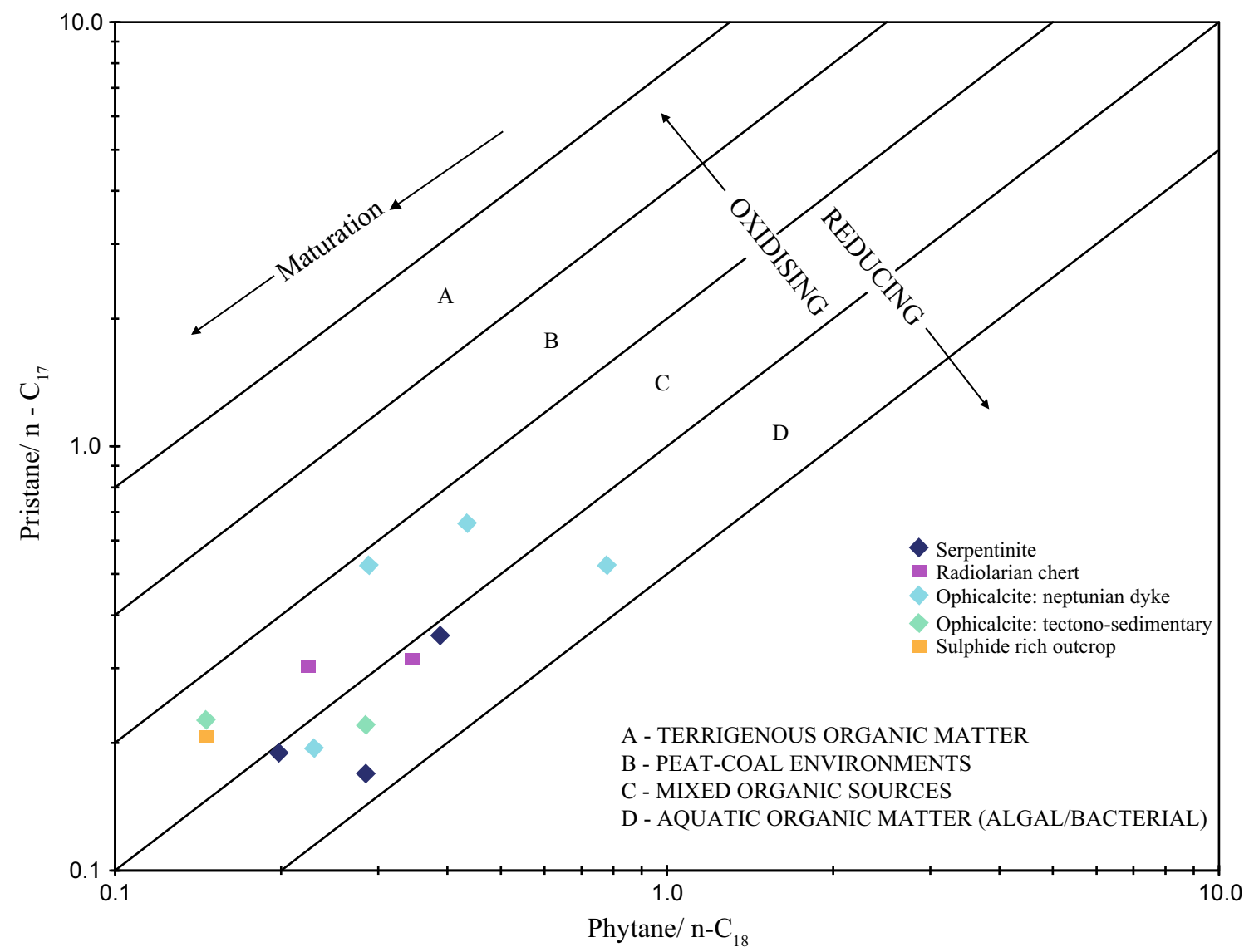

Fig. 7 Plot of pristane $/ n-\mathrm{C}_{17}$ versus phytane $/ n-\mathrm{C}_{18}$ for Totalp samples used to identify depositional environment and OM type (after Peters et al. 1999) 
Fig. 8 Sterane ternary distribution of the analysed samples for the $\alpha \beta \beta$ steranes of Totalp samples. The interpretation of depositional environment is from Patrycja Wójcik-Tabol and Ślączka (2015)

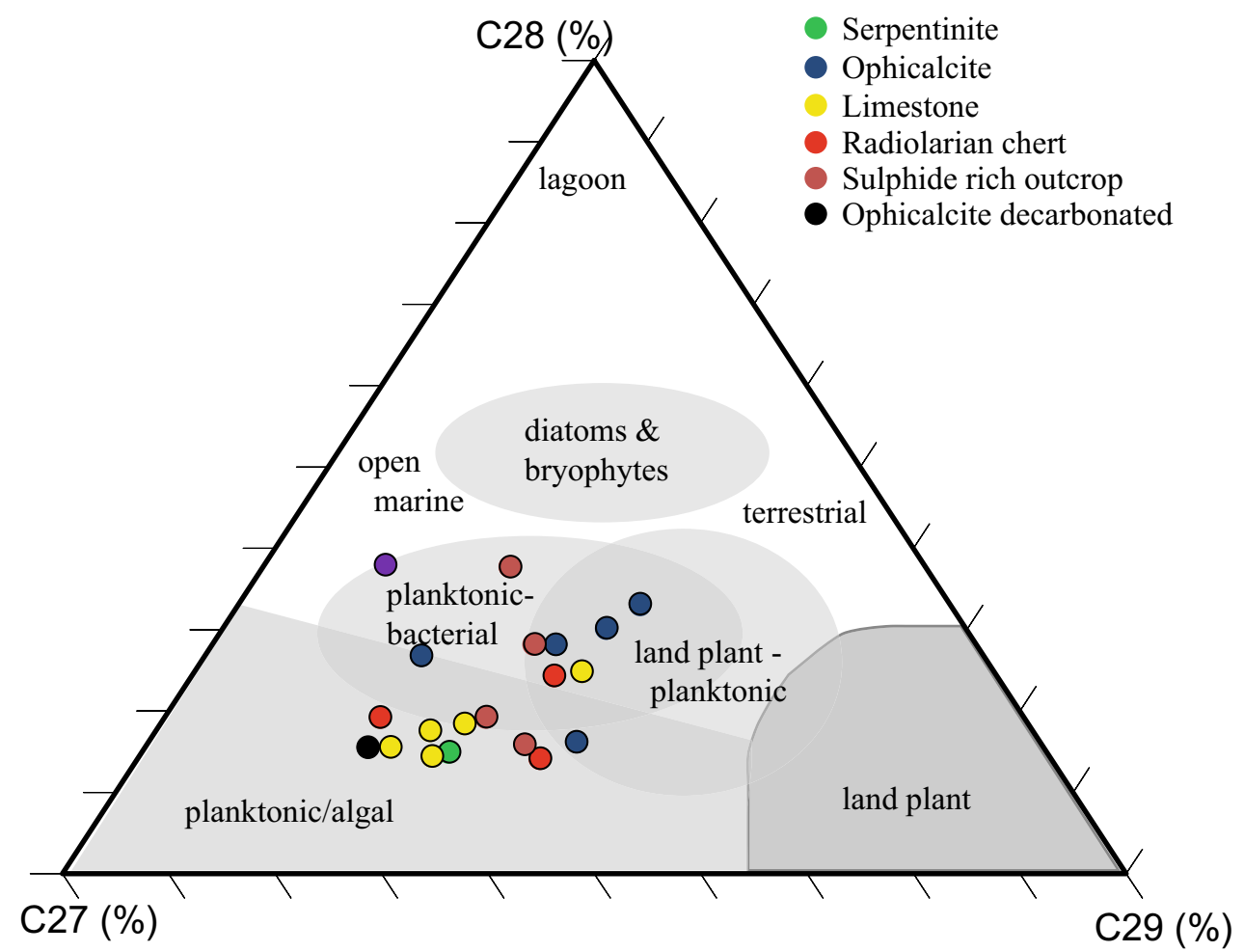

environment that might be expected at this fossil OCT. Sterane ternary diagrams are also commonly used to provide information on the source of OM in sedimentary rocks (Peters et al. 2005a). Comparison of Totalp steranes with predicted distributions of source materials (Fig. 8) are consistent with a mixed marine source of planktonic algal and bacterial OM (Gonçalves et al. 2013; Wójcik-Tabol and Ślaczka 2015) and are similar to OM deposited in marine settings during and since the Jurassic (Grantham and Wakefield 1988; Wójcik-Tabol and Ślączka 2015). Such a source for OM in the radiolarian cherts reflects the dominant planktonic signature of coccoliths and nanoconids (Manatschal et al. 2003). The variability in the sterane distributions most likely reflects spatial and temporal variability in environmental conditions during $\mathrm{OM}$ deposition.

In five samples (ophicalcite, limestone and samples from the sulphide bearing outcrop) with enough TOC to allow measurement of its stable isotopic composition, the determined values of $\delta^{13} \mathrm{C}_{\mathrm{VPDB}}$ organic of ca. -26.2 to $-27.4 \%$ (Table 2 ) are again consistent with an origin from marine OM ( $-26 \pm 7 \%$ ) (Schidlowski 1988; Hayes et al. $1990)$ and are similar to those found in hydrothermal systems from the Galapagos $\left(\delta^{13} \mathrm{C}=-27.4 \%\right.$ ) and the Guaymas Basin $\left(\delta^{13} \mathrm{C}=-25\right.$ to $-21 \%$ ) (Orem et al. 1990). Orem et al. (1990) argued that the OM in these hydrothermal systems derived from chemoautolithotrophic bacterial production. The carbon isotopic composition of methane in modern hydrothermal vents ranges from -8.8 to $-19.6 \%$ (e.g. TAG $26^{\circ} \mathrm{N}-8 /-9.5 \%$, Rainbow $36^{\circ} 14^{\prime} \mathrm{N}$ $-15.8 \%$, see Charlou et al. 2002; Lost City $30^{\circ} \mathrm{N}-13.6$ to -8.8\%o, Kelley et al. 2005; Bradley and Summons 2010). Fixation of hydrothermal methane by methanotrophs would be expected to lead to $\mathrm{OM}$ more depleted in ${ }^{13} \mathrm{C}$ by 15-30\%o (Summons et al. 1994; Schidlowski 2001; Templeton et al. 2006), i.e. in the range -23.8 to $-34.6 \%$ assuming the most conservative fractionation. Hence, isotopic data from the Totalp samples suggests that there could be a contribution from methanotrophic biomass; however the values are also consistent with marine-derived OM. Taken together with the molecular data and in the absence of specific methanotrophic biomarkers (e.g. crocetane), we consider that the Totalp hydrocarbons derive from marine OM.

\subsubsection{Thermal history of OM}

The distributions of PAHs are in part consistent with a high temperature origin (e.g. Killops and Massoud 1992), for example with pyrolytic residues (e.g. Geissman et al. 1967) arising from OM alteration by hydrothermal activity (Kawka and Simoneit 1990) or low-grade metamorphism (Heymann et al. 2003). Hence, the methyl-PAH/PAH ratios of $\leq 0.8$ observed in our samples are consistent with a pyrogenic source (Saha et al. 2009). However, the Fluo/Pyr ratio $<0.6$ of all the samples is lower than what would be expected of an exclusively pyrolytic source and indicates that lower temperature pathways of $\mathrm{PAH}$ formation also 
contribute to the HCs (Fabiańska et al. 2016). The biomarker maturation parameters of $\mathrm{C}_{27}$ steranes fall within values that might be expected within a temperature envelope consistent with a moderate thermal history (Fig. 6; ca. $80-150{ }^{\circ} \mathrm{C}$; Mackenzie et al. 1980; Peters et al. 2005a) and are therefore consistent with the temperature history of the basin (Früh-Green et al. 1990; Peters et al. 2005b). This suggests that where steranes are present, their degree of isomerisation reflects gradual maturation over time, rather than the pyrogenic process that may have yielded PAHs at the contact of hot rock with seawater OM.

\subsubsection{Origin of calcite veins}

The measured carbon and oxygen isotopic composition of carbonates are $0-2 \%$ and -11.7 to $-6.2 \%$, for $\delta^{13} \mathrm{C}_{\mathrm{VPDB}}$ and $\delta^{18} \mathrm{O}_{\mathrm{VPDB}}$, respectively and are similar to values previously reported for calcite veins in ophicalcite and late calcite veins collected in the Davos-Parsenn and Arosa areas (Fig. 4) (Früh-Green et al. 1990). The $\delta^{13} \mathrm{C}_{\mathrm{VPDB}}$ values are consistent with seawater-derived early diagenetic calcite (Fig. 4a) (Hudson 1977; Coleman et al. 1993; Heydari 1997). The $\delta^{18} \mathrm{O}_{\mathrm{VPDB}}$ values of the calcite veins for the majority of samples vary between -11.7 and $-6.2 \%$ and indicate calcite precipitation during shallow burial $(<250 \mathrm{~m})$, not influenced by organic carbon derived $\mathrm{CO}_{2}$ but typical of Cretaceous calcite (Dix and Mullins 1992; Heydari 1997). One sample (radiolarian chert) has a negative calcite carbon isotope value perhaps indicating the influence of $\mathrm{CO}_{2}$ delivered from diagenesis of OM (Heydari 1997).

\subsubsection{OM in serpentinite-mechanism of emplacement}

The occurrence of HCs in the serpentinite rocks of Totalp is at first sight surprising. Schwarzenbach et al. (2013) listed the five main sources of organic carbon (OC) that can be preserved in basement rocks, namely: seawater, mantle, Fischer-Tropsh-like reactions $(\mathrm{F}-\mathrm{T})$, in situ production from microbial activity in the basement rock, and, thermogenic decomposition of OM. The hydrocarbons recovered from the Totalp serpentinites and the OC have isotopic compositions consistent with an origin from marine OM, i.e. from a seawater source rather than from in situ production or abiotic F-T reactions. Therefore, the probable origin of the OC preserved in the rocks is from dissolved

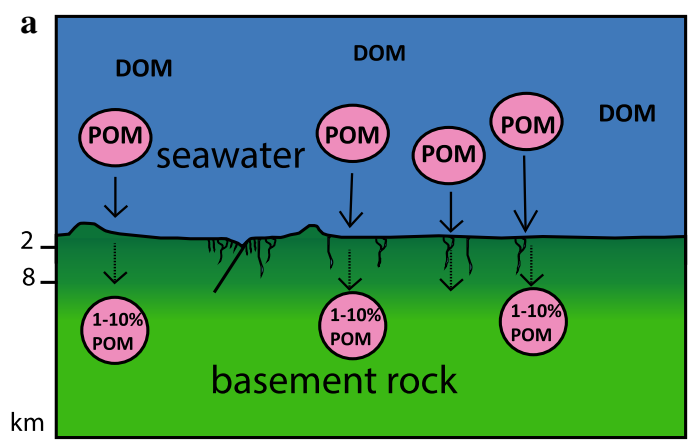

c

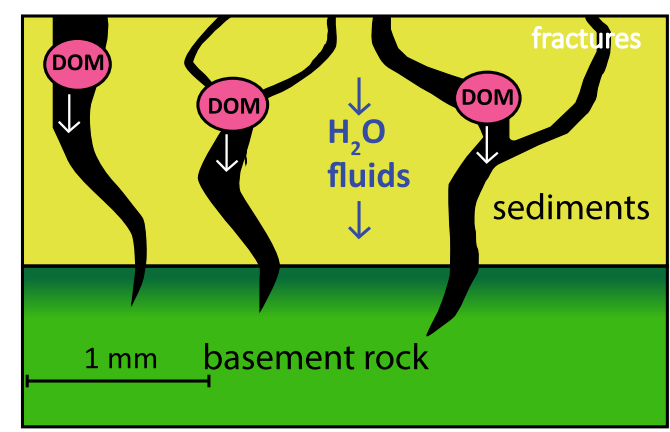

b

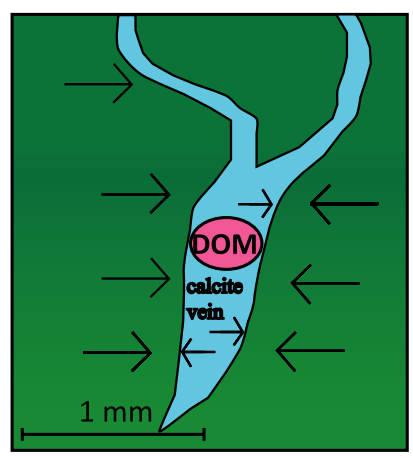

d 2 um

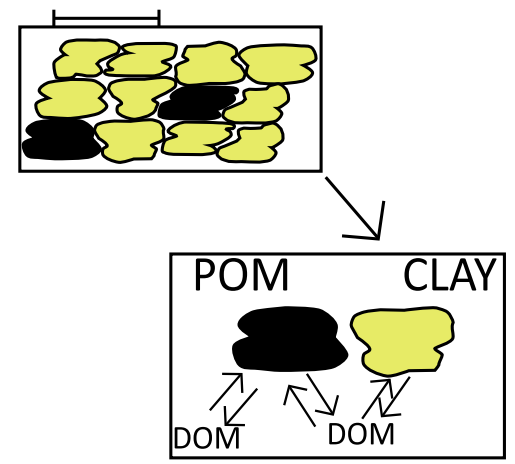

Fig. 9 Conceptual model explaining origin and migration of OM from the seawater into different lithologies in the Totalp unit. a The $\mathrm{OM}$ is represented by particulate and dissolved organic matter (POM and DOM, respectively). The OM infiltrates the basement rock by rock-fluid circulation. b Some OM may be deposited within the carbonate veins (e.g. calcite veins). c OM circulates with fluids through fractures and porosity of sediments to migrate into the basement rock. d OM is preserved at the surfaces and in the interlayer surfaces of clay minerals in the sediments 
and particulate organic carbon (DOC and POC) derived from seawater or thermal alteration of $\mathrm{OM}$ in sediments that then migrated to the basement rock within fluids (Fig. 9a). However, there could be different pathways of emplacement of $\mathrm{OM}$ in the serpentinites.

The OM could have been deposited within the two types of precipitated carbonate found in the serpentinite, namely the mechanically deposited carbonate that fills fractures, or via pore fluids fuelling the formation of calcite veins (Fig. 9b; Bernoulli and Weissert 1985; Früh-Green et al. 1990). The latter has an isotopic composition consistent with seawater carbonate and any DOM transported with the pore fluids would be trapped within the calcite matrix on precipitation (Figs. 4 and 9b). The presence of ophicalcite and the numerous calcite veins from the time of exhumation indicates a high supply of dissolved inorganic carbon (Ménez et al. 2012). As the OM clearly has a marine origin, it could have been emplaced by the first main phase of fluid-rock interactions at the ocean floor and the tectonosedimentary and hydrothermal processes described by Früh-Green et al. (1990). The OM may have migrated with seawater through fractures in the sediment into the basement rock (Fig. 9c; Delacour et al. 2008). These fractures formed by tectonic and crystallization stresses, which are not reliant on matrix permeability (Farough et al. 2016). Where initial contact between DOM-containing fluid and rock was at relatively high temperature, this could have led to the formation of the "pyrolytic" PAHs.

With respect to the sedimentary facies, organic carbon preservation is linked to grain size (or mineral surface area) and oxygen exposure after deposition (Fig. 9d; Hartnett et al. 1998; Kennedy et al. 2002). Clay minerals, one of the constituents of shale sediments found in the Totalp unit, strongly retain DOM both on the external surfaces and interlayer spaces of clay particles (Kennedy et al. 2002). However the Totalp sediments have low TOC values and could been highly oxidised during deposition or diagenesis. During deposition of shales, OM is also deposited as discrete biogenic particles, but largely these are not preserved; rather clays, particularly smectites, facilitate the absorption of DOM and POM from seawater and pore-fluids, and preserve it during burial (Kennedy et al. 2002).

In summary, $\mathrm{OM}$ in the exhumed mantle rocks at Totalp is of marine origin that migrated into the serpentinite most likely from the overlying seawater or sediment cover (Simoneit et al. 1978; Simoneit and Philp 1982). Our results are consistent with previous studies that show a lack of, or only minor formation of the $\mathrm{CH}_{4}$ and $\mathrm{H}_{2}$ needed for the production of $\mathrm{OM}$ involving serpentinization at low-temperature (McCollom and Donaldson 2016) and that the molecules necessary for life at hydrothermal systems are formed during the abiotic degradation of existing $\mathrm{OM}$ at low temperatures on the ocean floor (Reeves et al. 2014).

\section{Conclusions}

We provide evidence for the preservation of traces of $\mathrm{OM}$ originally deposited in a reducing marine environment in serpentinized mantle rocks and overlying sediments, but with no indication that the $\mathrm{OM}$ was generated from methanotrophic bio-systems. The presence of OM within serpentinized mantle raises two questions; how much is there and how is this OM distributed in depth? Drilling to recover rock cores from the Totalp area would allow sampling of serpentinized mantle deeper than surface outcrops and would shed light on the depth distribution of OM and its composition.

Acknowledgements The Margin modelling program MM3 is acknowledged for funding. A. Thompson, S. Crowley, S. Blackbird, G. Harriman, E. Fisher, J. Utley, N. Carr and S. Petev are thanked for scientific and technical assistance. Two anonymous reviewers and the editor Stefan Schmid are thanked for their helpful comments that improved the manuscript.

Open Access This article is distributed under the terms of the Creative Commons Attribution 4.0 International License (http://crea tivecommons.org/licenses/by/4.0/), which permits unrestricted use, distribution, and reproduction in any medium, provided you give appropriate credit to the original author(s) and the source, provide a link to the Creative Commons license, and indicate if changes were made.

$\begin{array}{ll}\text { Glossary } & \\ \text { DOM } & \text { Dissolved organic matter } \\ \text { GC } & \text { Gas chromatography } \\ \text { GC-MS } & \text { Gas chromatography-mass spectrometry } \\ \text { HC } & \text { Hydrocarbon } \\ \text { HCL } & \text { Hydrochloric acid } \\ \text { OCT } & \text { Ocean-continent transition } \\ \text { OM } & \text { Organic matter } \\ \text { PAH } & \text { Polynuclear aromatic hydrocarbons } \\ \text { P } & \text { Phenanthrene } \\ \text { Fluo } & \text { Fluoranthene } \\ \text { Pyr } & \text { Pyrene } \\ \text { Chry } & \text { Chrysene } \\ \text { BaA } & \text { Benzo(a)anthracene } \\ \text { BbF } & \text { Benzo(b)fluoranthene } \\ \text { BaP } & \text { Benzo(a)pyrene } \\ \text { IndPy } & \text { Indeno(1,2,3-cd)pyrene } \\ \text { BghiP } & \text { Benzo(ghi)perylene } \\ \text { DBT } & \text { Dibenzothiophene } \\ 3,2,1 \text { and } 9 & \text { 3-,2-,1- and 9-methylphenanthrene } \\ \text { MPs } & \\ \text { POM } & \text { Particle organic matter } \\ \text { POC } & \text { Particle organic carbon } \\ \text { PPM } & \text { Parts per million (1 ppm = 1 mg/l; } \\ & 1 \text { mg/kg) }\end{array}$




\section{Steranes}

$\mathrm{C} 27 \beta \alpha 20 \mathrm{~S}$

$\mathrm{C} 27 \beta \alpha 20 \mathrm{R}$

$\mathrm{C} 27 \alpha \beta 20 \mathrm{~S}$

$\mathrm{C} 27 \alpha \beta 20 \mathrm{R}$

$\mathrm{C} 28 \beta \alpha 20 \mathrm{~S}$

$\mathrm{C} 28 \beta \alpha 20 \mathrm{R}$

$\mathrm{C} 27 \alpha \alpha \alpha 20 \mathrm{~S}$

$\mathrm{C} 27 \alpha \beta \beta 20 \mathrm{R}$

C27 $\alpha \beta \beta 20 \mathrm{~S}$

C27 $\alpha \alpha \alpha 20 \mathrm{R}$

C28 $\alpha \alpha \alpha 20 S$

$\mathrm{C} 28 \alpha \beta \beta 20 \mathrm{R}$

C28 $\alpha \beta \beta 20 \mathrm{~S}$

$\mathrm{C} 28 \alpha \alpha \alpha 20 \mathrm{R}$

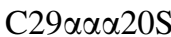

C29 $\alpha \beta \beta 20 \mathrm{R}$

C29 $\alpha \beta \beta 20 S$

C29 $\alpha \alpha \alpha 20 \mathrm{R}$

TOC

TC

XRD

$\%$

\section{References}

Arshad, A., Speth, D. R., de Graaf, R. M., den Camp, H. J. O., Jetten, M. S., \& Welte, C. U. (2015). A metagenomics-based metabolic model of nitrate-dependent anaerobic oxidation of methane by Methanoperedens-like archaea. Frontiers in microbiology, 6, 1423.

Bailey, S. W. (1969). Polytypism of trioctahedral 1: 1 layer silicates. Clays and Clay Minerals, 17, 355-371.

Beard, J. S., \& Hopkinson, L. (2000). A fossil, serpentinizationrelated hydrothermal vent, Ocean Drilling Program Leg 173, Site 1068 (Iberia Abyssal Plain): Some aspects of mineral and fluid chemistry. Journal of Geophysical Research: Solid Earth, 105, 16527-16539.

Berner, R. A. (1984). Sedimentary pyrite formation: An update. Geochimica et Cosmochimica Acta, 48, 605-615.

Bernoulli, D., \& Jenkyns, H. C. (2009). Ophiolites in ocean-continent transitions: from the Steinmann Trinity to sea-floor spreading. Comptes Rendus Geoscience, 341, 363-381.

Bernoulli, D., Manatschal, G., Desmurs, L., \& Muntener, O. (2003). Where did Gustav Steinmann see the trinity? Back to the roots of an Alpine ophiolite concept. Special Papers-Geological Society of America, 373, 93-110.

Bernoulli, D., \& Weissert, H. (1985). Sedimentary fabrics in Alpine ophicalcites, south Pennine Arosa zone, Switzerland. Geology, 13, 755-758.

Blumenberg, M., Seifert, R., Reitner, J., Pape, T., \& Michaelis, W. (2004). Membrane lipid patterns typify distinct anaerobic methanotrophic consortia. Proceedings of the National Academy of Sciences of the United States of America, 101, 11111-11116.

Bougault, H., Charlou, J. L., Fouquet, Y., Needham, H. D., Vaslet, N., Appriou, P., et al. (1993). Fast and slow spreading ridges: Structure and hydrothermal activity, ultramafic topographic highs, and CH4 output. Journal of Geophysical Research: Solid Earth, 98, 9643-9651.

Bradley, A. S., \& Summons, R. E. (2010). Multiple origins of methane at the Lost City Hydrothermal Field. Earth and Planetary Science Letters, 297, 34-41.

Burkhard, D. J., \& O’Neil, J. R. (1988). Contrasting serpentinization processes in the eastern Central Alps. Contributions to Mineralogy and Petrology, 99, 498-506.

Cardace, D., Hoehler, T., McCollom, T., Schrenk, M., Carnevale, D., Kubo, M., et al. (2013). Establishment of the Coast Range ophiolite microbial observatory (CROMO): Drilling objectives and preliminary outcomes. Scientific Drilling, 16, 45-55.

Charlou, J. L., Dmitriev, L., Bougault, H., \& Needham, H. D. (1988). Hydrothermal $\mathrm{CH} 4$ between $12^{\circ} \mathrm{N}$ and $15^{\circ} \mathrm{N}$ over the MidAtlantic Ridge. Deep Sea Research Part A. Oceanographic Research Papers, 35, 121-131.

Charlou, J. L., \& Donval, J. P. (1993). Hydrothermal methane venting between $12^{\circ} \mathrm{N}$ and $26^{\circ} \mathrm{N}$ along the Mid-Atlantic Ridge. Journal of Geophysical Research, 98, 9625-9642.

Charlou, J. L., Donval, J. P., Fouquet, Y., Jean-Baptiste, P., \& Holm, N. (2002). Geochemistry of high $\mathrm{H}_{2}$ and $\mathrm{CH}_{4}$ vent fluids issuing from ultramafic rocks at the Rainbow hydrothermal field (36¹4'N, MAR). Chemical Geology, 191, 345-359.

Charlou, J. L., Fouquet, Y., Bougault, H., Donval, J. P., Etoubleau, J., Jean-Baptiste, P., et al. (1998). Intense CH4 plumes generated by serpentinization of ultramafic rocks at the intersection of the $15^{\circ} 20^{\prime} \mathrm{N}$ fracture zone and the Mid-Atlantic Ridge. Geochimica et Cosmochimica Acta, 62, 2323-2333.

Coleman, M., Raiswell, R., Brown, A., Curtis, C., Aplin, A., Ortoleva, P., et al. (1993). Microbial mineralization of organic matter: Mechanisms of self-organization and inferred rates of precipitation of diagenetic minerals [and Discussion]. Philosophical Transactions of the Royal Society of London A: Mathematical, Physical and Engineering Sciences, 344, 69-87.

Craig, H. (1957). Isotopic standards for carbon and oxygen and correction factors for mass-spectrometric analysis of carbon dioxide. Geochimica et Cosmochimica Acta, 12, 133-149.

Delacour, A., Früh-Green, G. L., Bernasconi, S. M., Schaeffer, P., \& Kelley, D. S. (2008). Carbon geochemistry of serpentinites in the Lost City Hydrothermal System $\left(30^{\circ} \mathrm{N}\right.$, MAR). Geochimica et Cosmochimica Acta, 72, 3681-3702.

Desmurs, L., Müntener, O., \& Manatschal, G. (2002). Onset of magmatic accretion within a magma-poor rifted margin: A case study from the Platta ocean-continent transition, eastern Switzerland. Contributions to Mineralogy and Petrology, 144, 365-382.

Dias, Á. S., \& Barriga, F. J. (2006). Mineralogy and geochemistry of hydrothermal sediments from the serpentinite-hosted Saldanha hydrothermal field (36 34 $\mathrm{N} ; 3326^{\prime} \mathrm{W}$ ) at MAR. Marine Geology, 225, 157-175.

Dix, G. R., \& Mullins, H. T. (1992). Shallow-burial diagenesis of deep-water carbonates, northern Bahamas: Results from deepocean drilling transects. Geological Society of America Bulletin, 104, 303-315. 
Etiope, G., \& Ionescu, A. (2014). Low-temperature catalytic $\mathrm{CO}_{2}$ hydrogenation with geological quantities of ruthenium: A possible abiotic $\mathrm{CH}_{4}$ source in chromitite-rich serpentinized rocks. Geofluids, 5, 438-452.

Fabiańska, M., Kozielska, B., Bielaczyc, P., Woodburn, J., \& Konieczyński, J. (2016). Geochemical markers and polycyclic aromatic hydrocarbons in solvent extracts from diesel engine particulate matter. Environmental Science and Pollution Research, 23, 6999-7011.

Farough, A., Moore, D., Lockner, D., \& Lowell, R. (2016). Evolution of fracture permeability of ultramafic rocks undergoing serpentinization at hydrothermal conditions: An experimental study. Geochemistry, Geophysics, Geosystems, 17, 44-55.

Frazer, J. W., \& Crawford, R. (1963). Modifications in the simultaneous determination of carbon, hydrogen, and nitrogen. $\mathrm{Mi}$ crochimica Acta, 51, 561-566.

Friedman, I., \& O’Neil, J. R. (1977), Data of geochemistry: Compilation of stable isotope fractionation factors of geochemical interest). US Government Printing Office.

Früh-Green, G. L., Weissert, H., \& Bernoulli, D. (1990). A multiple fluid history recorded in Alpine ophiolites. Journal of the Geological Society, 147, 959-970.

Geissman, T., Sim, K., \& Murdoch, J. (1967). Organic minerals. Picene and chrysene as constituents of the mineral curtisite (idrialite). Cellular and Molecular Life Sciences, 23, 793-794.

Gonçalves, P. A., Mendonça Filho, J. G., Mendonça, J. O., da Silva, T. F., \& Flores, D. (2013). Paleoenvironmental characterization of a Jurassic sequence on the Bombarral sub-basin (Lusitanian basin, Portugal): Insights from palynofacies and organic geochemistry. International Journal of Coal Geology, 113, 27-40.

Gràcia, E., Charlou, J. L., Radford-Knoery, J., \& Parson, L. M. (2000). Non-transform offsets along the Mid-Atlantic Ridge south of the Azores $(38 \mathrm{~N}-34 \mathrm{~N})$ : ultramafic exposures and hosting of hydrothermal vents. Earth and Planetary Science Letters, 177, 89-103.

Grantham, P. J., \& Wakefield, L. L. (1988). Variations in the sterane carbon number distributions of marine source rock derived crude oils through geological time. Organic Geochemistry, 12, 61-73.

Haroon, M. F., Hu, S., Shi, Y., Imelfort, M., Keller, J., Hugenholtz, P., et al. (2013). Anaerobic oxidation of methane coupled to nitrate reduction in a novel archaeal lineage. Nature, 500, 567-570.

Hartnett, H. E., Keil, R. G., Hedges, J. I., \& Devol, A. H. (1998). Influence of oxygen exposure time on organic carbon preservation in continental margin sediments. Nature, 391, 572-575.

Hayes, J. M., Freeman, K. H., Popp, B. N., \& Hoham, C. H. (1990). Compound-specific isotopic analyses: A novel tool for reconstruction of ancient biogeochemical processes. Organic Geochemistry, 16, 1115-1128.

Haymon, R. M. (1983). Hydrothermal deposition on the East Pacific Rise at 21 N. Journal of Geochemical Exploration, 19, 493-495.

Haymon, R. M. (1989). Hydrothermal processes and products on the Galapagos Rift and East Pacific Rise. In D. M. Hussong, E. L. Winterer, \& R. W. Decker (Eds.), The eastern pacific ocean and Hawaii (pp. 125-144). Denver: Geoological Society of America.

Heydari, E. (1997). Hydrotectonic models of burial diagenesis in platform carbonates based on formation water geochemistry in North American sedimentary basins. In I. P. Montanez, J. M. Gregg, \& K. L. Shelton (Eds.), Basin-wide diagenetic patterns: Integrated petrologic, geochemical and hydrologic considerations (pp. 53-79). Tulsa: Society of Economic Paleontologists and Mineralogists, Special Publication.

Heymann, D., Jenneskens, L. W., Jehlicka, J., Koper, C., \& Vlietstra, E. J. (2003). Biogenic fullerenes? International Journal of Astrobiology, 2, 179-183.
Hinrichs, K.-U., Summons, R. E., Orphan, V., Sylva, S. P., \& Hayes, J. M. (2000). Molecular and isotopic analysis of anaerobic methane-oxidizing communities in marine sediments. Organic Geochemistry, 31, 1685-1701.

Holm, N. G., Dumont, M., Ivarsson, M., \& Konn, C. (2006). Alkaline fluid circulation in ultramafic rocks and formation of nucleotide constituents: A hypothesis. Geochemical Transactions, 7, 1-13.

Hudson, J. (1977). Stable isotopes and limestone lithification. Journal of the Geological Society, 133, 637-660.

Jamtveit, B., \& Hammer, Ø. (2012). Sculpting of rocks by reactive fluids. Geochemical Perspectives, 1, 341-342.

Kawka, O. E., \& Simoneit, B. R. (1990). Polycyclic aromatic hydrocarbons in hydrothermal petroleums from the Guaymas Basin spreading center. Applied Geochemistry, 5, 17-27.

Kelley, D. S., \& Delaney, J. R. (1987). Two-phase separation and fracturing in mid-ocean ridge gabbros at temperatures greater than $700{ }^{\circ}$ C. Earth and Planetary Science Letters, 83, 53-66.

Kelley, D. S., Karson, J. A., Blackman, D. K., Fruh-Green, G. L., Butterfield, D. A., Lilley, M. D., et al. (2001). An off-axis hydrothermal vent field near the Mid-Atlantic Ridge at 30[deg] N. Nature, 412, 145-149.

Kelley, D. S., Karson, J. A., Früh-Green, G. L., Yoerger, D. R., Shank, T. M., Butterfield, D. A., et al. (2005). A serpentinitehosted ecosystem: The Lost City hydrothermal field. Science, 307, 1428-1434.

Kelley, D. S., \& Shank, T. M. (2010). Hydrothermal systems: A decade of discovery in slow spreading environments. In C. W. Devey P. A. Rona, J. Dyment and B. J. Murton (ed.), Diversity of hydrothermal systems on slow Spreading ocean ridges, (pp. 369-407) Washington: American Geophysical Union.

Kennedy, M. J., Pevear, D. R., \& Hill, R. J. (2002). Mineral surface control of organic carbon in black shale. Science, 295, 657-660.

Killops, S., \& Massoud, M. (1992). Polycyclic aromatic hydrocarbons of pyrolytic origin in ancient sediments: Evidence for Jurassic vegetation fires. Organic Geochemistry, 18, 1-7.

Kiriakoulakis, K. (1997). Organic geochemistry of early diagenetic concretions. EOES, PhD (350).

Lemoine, M., Tricart, P., \& Boillot, G. (1987). Ultramafic and gabbroic ocean floor of the Ligurian Tethys (Alps, Corsica, Apennines): In search of a genetic imodel. Geology, 15, 622-625.

Mackenzie, A., Patience, R., Maxwell, J., Vandenbroucke, M., \& Durand, B. (1980). Molecular parameters of maturation in the Toarcian shales, Paris Basin, France-I. Changes in the configurations of acyclic isoprenoid alkanes, steranes and triterpanes. Geochimica et Cosmochimica Acta, 44, 1709-1721.

Manatschal, G., \& Bernoulli, D. (1999). Architecture and tectonic Evolution of nonvolcanic margins: Present-day Galicia and ancient Adria. Tectonics, 18, 1099-1119.

Manatschal, G., Froitzheim, N., Rubenach, M., \& Turrin, B. D. (2001). The role of detachment faulting in the formation of an ocean-continent transition: Insights from the Iberia Abyssal Plain. Geological Society, London, Special Publications, 187, 405-428.

Manatschal, G., Muntener, O., Desmurs, L., \& Bernoulli, D. (2003). An ancient ocean-continent transition in the Alps: The Totalp, Err-Platta, and Malenco units in the eastern Central Alps (Graubünden and northern Italy). Eclogae Geologicae Helvetiae, 96, 131-146.

McCollom, T. M. (2013). Laboratory simulations of abiotic hydrocarbon formation in Earth's deep subsurface. Reviews in Mineralogy and Geochemistry, 75, 467-494.

McCollom, T. M., \& Donaldson, C. (2016). Generation of hydrogen and methane during experimental low-temperature reaction of ultramafic rocks with water. Astrobiology, 16, 389-406. 
McCollom, T. M., \& Seewald, J. S. (2013). Serpentinites, hydrogen, and life. Elements, 9, 129-134.

McCollom, T. M., \& Shock, E. L. (1997). Geochemical constraints on chemolithoautotrophic metabolism by microorganisms in seafloor hydrothermal systems. Geochimica et Cosmochimica Acta, 61, 4375-4391.

McCrea, J. M. (1950). On the isotopic chemistry of carbonates and a paleotemperature scale. The Journal of Chemical Physics, 18, 849-857.

Ménez, B., Pasini, V., \& Brunelli, D. (2012). Life in the hydrated suboceanic mantle. Nature Geoscience, 5, 133-137.

Mohn, G., Manatschal, G., Müntener, O., Beltrando, M., \& Masini, E. (2010). Unravelling the interaction between tectonic and sedimentary processes during lithospheric thinning in the Alpine Tethys margins. International Journal of Earth Sciences, 99, $75-101$.

Montgomery, H., \& Kerr, A. C. (2009). Rethinking the origins of the red chert at La Désirade, French West Indies. Geological Society, London, Special Publications, 328, 457-467.

Mottl, M. J., Komor, S. C., Fryer, P., \& Moyer, C. L. (2003). Deepslab fluids fuel extremophilic Archaea on a Mariana forearc serpentinite mud volcano: Ocean Drilling Program Leg 195. Geochemistry, Geophysics, Geosystems, 4, 1525-2027.

Müntener, O., Manatschal, G., Desmurs, L., \& Pettke, T. (2010). Plagioclase peridotites in ocean-continent transitions: Refertilized mantle domains generated by melt stagnation in the shallow mantle lithosphere. Journal of Petrology, 51, 255-294.

Müntener, O., Pettke, T., Desmurs, L., Meier, M., \& Schaltegger, U. (2004). Refertilization of mantle peridotite in embryonic ocean basins: Trace element and $\mathrm{Nd}$ isotopic evidence and implications for crust-mantle relationships. Earth and Planetary Science Letters, 221, 293-308.

Orem, W. H., Spiker, E. C., \& Kotra, R. K. (1990). Organic matter in hydrothermal metal ores and hydrothermal fluids. Applied Geochemistry, 5, 125-134.

Orphan, V. J., House, C. H., Hinrichs, K.-U., McKeegan, K. D., \& DeLong, E. F. (2001). Methane-consuming archaea revealed by directly coupled isotopic and phylogenetic analysis. Science, 293, 484-487.

Peltzer, E., \& Gagosian, R. (1989). Organic geochemistry of aerosols over the Pacific Ocean. Chemical Oceanography, 10, 281-338.

Peters, T. (1968). Distribution of $\mathrm{Mg}, \mathrm{Fe}, \mathrm{A} 1, \mathrm{Ca}$ and $\mathrm{Na}$ in Coexisting Olivine, Orthopyroxene and Clinopyroxene in the Totalp Serpentinite (Davos, Switzerland) and in the Alpine Metamorphosed Malenco Serpentinite (N. Italy). Contributions to Mineralogy and Petrology, 18, 65-75.

Peters, K. E., Fraser, T. H., Amris, W., Rustanto, B., \& Hermanto, E. (1999). Geochemistry of crude oils from eastern Indonesia. The American Association of Petroleum Geologists, 83, 1927-1942.

Peters, T., \& Stettler, A. (1987). Radiometric age, thermobarometry and mode of emplacement of the Totalp peridotite in the Eastern Swiss Alps. Schweizerische Mineralogische und Petrographische Mitteilungen, 67, 285-294.

Peters, K., Walters, C., \& Moldowan, J. (2005a). The biomarker guide: 2, Biomarkers and isotopes in petroleum systems and earth history. Cambridge: Cambridge University Press.

Peters, K. E., Walters, C. C., \& Moldowan, J. M. (2005b). The biomarker guide: 1, Biomarkers and isotopes in the environment and human history. Cambridge: Cambridge University Press.

Picazo, S., Manatschal, G., Cannat, M., \& Andréani, M. (2013). Deformation associated to exhumation of serpentinized mantle rocks in a fossil Ocean Continent Transition: The Totalp unit in SE Switzerland. Lithos, 175-176, 255-271.

Proskurowski, G., Lilley, M. D., Seewald, J. S., Früh-Green, G. L., Olson, E. J., Lupton, J. E., et al. (2008). Abiogenic hydrocarbon production at Lost City hydrothermal field. Science, 319, 604-607.

Raghoebarsing, A. A., Pol, A., Van de Pas-Schoonen, K. T., Smolders, A. J., Ettwig, K. F., Rijpstra, W. I. C., et al. (2006). A microbial consortium couples anaerobic methane oxidation to denitrification. Nature, 440, 918-921.

Reeves, E. P., McDermott, J. M., \& Seewald, J. S. (2014). The origin of methanethiol in midocean ridge hydrothermal fluids. Proceedings of the National Academy of Sciences of the United States of America, 111, 5474-5479.

Rona, P. A. (1984). Hydrothermal mineralization at seafloor spreading centers. Earth-Science Reviews, 20, 1-104.

Rona, P., Bougault, H., Charlou, J., Appriou, P., Nelsen, T., Trefry, J., et al. (1992). Hydrothermal circulation, serpentinization, and degassing at a rift valley-fracture zone intersection: Mid-Atlantic Ridge near 15 N, 45 W. Geology, 20, 783-786.

Rona, P., Widenfalk, L., \& Boström, K. (1987). Serpentinized ultramafics and hydrothermal activity at the Mid-Atlantic Ridge crest near 15 N. Journal of Geophysical Research: Solid Earth, 92, 1417-1427.

Saha, M., Togo, A., Mizukawa, K., Murakami, M., Takada, H., Zakaria, M. P., et al. (2009). Sources of sedimentary PAHs in tropical Asian waters: Differentiation between pyrogenic and petrogenic sources by alkyl homolog abundance. Marine Pollution Bulletin, 58, 189-200.

Schidlowski, M. (1988). A 3,800-million-year isotopic record of life from carbon in sedimentary rocks. Nature, 333, 313-318.

Schidlowski, M. (2001). Carbon isotopes as biogeochemical recorders of life over $3.8 \mathrm{Ga}$ of Earth history: evolution of a concept. Precambrian Research, 106, 117-134.

Schmid, S. M., Fügenschuh, B., Kissling, E., \& Schuster, R. (2004). Tectonic map and overall architecture of the Alpine orogen. Eclogae Geologicae Helvetiae, 97, 93-117.

Schwarzenbach, E. M., Früh-Green, G. L., Bernasconi, S. M., Alt, J. C., \& Plas, A. (2013). Serpentinization and carbon sequestration: A study of two ancient peridotite-hosted hydrothermal systems. Chemical Geology, 351, 115-133.

Seifert, W. K., \& Moldowan, J. M. (1980). The effect of thermal stress on source-rock quality as measured by hopane stereochemistry. Physics and Chemistry of the Earth, 12, 229-237.

Shock, E. L., McCollom, T., \& Schulte, M. D. (2002). The emergence of metabolism from within hydrothermal systems. In J. Wiegel \& A. W. W. Michael (Eds.), Thermophiles: the keys to molecular evolution and the origin of life (pp. 59-76). Washington, DC: CRC Press.

Simoneit, B. R., Brenner, S., Peters, K., \& Kaplan, I. (1978). Thermal alteration of Cretaceous black shale by basaltic intrusions in the Eastern Atlantic. Nature, 273, 501-504.

Simoneit, B., \& Philp, R. (1982). Organic geochemistry of lipids and karogen and the effects of basalt intrusions in unconsolidated oceanic sediments site 477, site 478 and site 481, Guaymas basin, Gulf of California. In J. R. Curray \& D. G. Moore (Eds.), Initial reports of the deep sea drilling project (pp. 883-904). Washington, DC: U.S. Gouvernment Printing office.

Sofer, Z. (1980). Preparation of carbon dioxide for stable carbon isotope analysis of petroleum fractions. Analytical Chemistry, 52, 1389-1391.

Styrt, M., Brackmann, A., Holland, H., Clark, B., Pisutha-Arnond, V., Eldridge, C., et al. (1981). The mineralogy and the isotopic composition of sulfur in hydrothermal sulfide/sulfate deposits on the East Pacific Rise, $21 \mathrm{~N}$ latitude. Earth and Planetary Science Letters, 53, 382-390.

Summons, R. E., Jahnke, L. L., \& Roksandic, Z. (1994). Carbon isotopic fractionation in lipids from methanotrophic bacteria: Relevance for interpretation of the geochemical record of biomarkers. Geochimica et Cosmochimica Acta, 58, 2853-2863. 
Swart, P. K., Burns, S., \& Leder, J. (1991). Fractionation of the stable isotopes of oxygen and carbon in carbon dioxide during the reaction of calcite with phosphoric acid as a function of temperature and technique. Chemical Geology: Isotope Geoscience section, 86, 89-96.

Templeton, A. S., Chu, K.-H., Alvarez-Cohen, L., \& Conrad, M. E. (2006). Variable carbon isotope fractionation expressed by aerobic $\mathrm{CH}$ 4-oxidizing bacteria. Geochimica et Cosmochimica Acta, 70, 1739-1752.

van Acken, D., Becker, H., Walker, R. J., McDonough, W. F., Wombacher, F., Ash, R. D., et al. (2010). Formation of pyroxenite layers in the Totalp ultramafic massif (Swiss Alps)Insights from highly siderophile elements and Os isotopes. Geochimica et Cosmochimica Acta, 74, 661-683.

Villanueva, J., Grimalt, J. O., Cortijo, E., Vidal, L., \& Labeyriez, L. (1997). A biomarker approach to the organic matter deposited in the North Atlantic during the last climatic cycle. Geochimica et Cosmochimica Acta, 61, 4633-4646.

Weissert, H. J., \& Bernoulli, D. (1985). A transform margin in the Mesozoic Tethys: Evidence from the Swiss Alps. Geologische Rundschau, 74, 665-679.
Weissert, H., McKenzie, J., \& Channell, J. (1985). Natural variations in the carbon cycle during the Early Cretaceous. In E. T. Sundquist \& W. S. Broecker (Eds.), The carbon cycle and atmospheric CO: Natural variations Archean to present (pp. 531-545). Washington, DC: American Geophysical Union Geophysical Monograph.

Williams, L. A., Parks, G. A., \& Crerar, D. A. (1985). Silica diagenesis, I. Solubility controls. Journal of Sedimentary Research, 55, 301-311.

Wójcik-Tabol, P., \& Ślączka, A. (2015). Are Early Cretaceous environmental changes recorded in deposits of the Western part of the Silesian Nappe? A geochemical approach. Palaeogeography, Palaeoclimatology, Palaeoecology, 417, 293-308.

Wolff, G. A., Boardman, D., Horsfall, I., Sutton, I., Davis, N., Chester, R., et al. (1995). The biogeochemistry of sediments from the Madeira Abyssal Plain-preliminary results. Internationale Revue der gesamten Hydrobiologie und Hydrographie, 80, 333-349.

Zeng, Z., Niedermann, S., Chen, S., Wang, X., \& Li, Z. (2015). Noble gases in sulfide deposits of modern deep-sea hydrothermal systems: Implications for heat fluxes and hydrothermal fluid processes. Chemical Geology, 409, 1-11. 